\title{
Perioperative Genomic Profiles Using Structure-Specific Oligonucleotide Probes
}

Kirk J. Hogan, MD; James K. Burmester, PhD; Michael D. Caldwell, MD, PhD; Quinn H. Hogan, MD; Douglas B. Coursin, MD; Dawn N. Green, MS; Rebecca M.R. Selzer, PhD; Thomas P. Broderick, MD; Deborah A. Rusy, MD; Mark Poroli, BS; Anna L. Lutz, BS; Allison M. Sanders, BS; Mary C. Oldenburg, MS; James A. Koelbl, MS; Monika de Arruda-Indig, PhD; Jennifer L. Halsey, PharmD; Stephen P. Day, PhD; and Michael J. Domanico, PhD

Objectives: Many complications in the perioperative interval are associated with genetic susceptibilities that may be unknown in advance of surgery and anesthesia, including drug toxicity and inefficacy, thrombosis, prolonged neuromuscular blockade, organ failure and sepsis. The aims of this study were to design and validate the first genetic testing platform and panel designed for use in perioperative care, to establish allele frequencies in a target population, and to determine the number of mutant alleles per patient undergoing surgery.

Design/Setting/Participants and Methods: One hundred fifty patients at Marshfield Clinic, Marshfield, Wisconsin, 100 patients at the Medical College ofWisconsin Zablocki Veteran's Administration Medical Center, Milwaukee,Wisconsin, and 200 patients at the University of Wisconsin Hospitals and Clinics, Madison,Wisconsin undergoing surgery and anesthesia were tested for 48 polymorphisms in 22 genes including ABC, BChE, ACE, CYP2C9, CYP2C19, CYP2D6, CYP3A4, CYP3A5, $\beta 2 A R$, TPMT, F2, F5, F7, MTHFR, $T N F \alpha, T N F \beta, C C R 5, A p o E, H B B, M Y H 7, A B O$ and Gender (PRKY, PFKFBI). Using structure-specific cleavage of oligonucleotide probes (Invader, Third Wave Technologies, Inc., Madison, WI), 96-well plates were configured so that each well contained reagents for detection of both the wild type and mutant alleles at each locus.

Results: There were 21,600 genotypes confirmed in duplicate. After withdrawal of polymorphisms in non-pathogenic genes (i.e., the ABO blood group and gender-specific alleles), 376 of 450 patients were found to be homozygous for mutant alleles at one or more loci. Modes of two mutant homozygous loci and 10 mutant alleles in aggregate (i.e., the sum of homozygous and heterozygous mutant polymorphisms) were observed per patient.

Conclusions: Significant genetic heterogeneity that may not be accounted for by taking a family medical history, or by obtaining routine laboratory test results, is present in most patients presenting for surgery and may be detected using a newly developed genotyping platform.

Keywords: Genetic polymorphisms; Genetic predisposition testing; Genetic susceptibility; Genetic variation; Molecular diagnostic techniques; Oligonucleotide probes; Perioperative care; Perioperative complications; Pharmacogenetics

Corresponding Author: Kirk J. Hogan, MD, Department of Anesthesiology, University of Wisconsin School of Medicine and Public Health, B6/3 I 9 Clinical Sciences Center, 600 Highland Avenue, Madison, WI 53792, Tel: 608-263-8I00, Fax: 608-263-0575, Email: khogan@wiscmail.wisc.edu
Received: December 29, 2008

Revised: March 5, 2009

Accepted: March II, 2009

doi: $10.3121 / \mathrm{cmr} .2009 .837$

Grant Support: Grant No. IR43GM643I7-0I from the National Institutes of Health, Bethesda, Maryland. Dr. K. Hogan, Dr. Caldwell and Dr. Q. Hogan received research support and consulting fees from the NIH grant. Dr. Domanico, Dr. de Arruda-Indig, Dr. Day, Ms. Lutz, Ms. Sanders, Ms. Oldenburg, and Mr. Koelbl were employed by Third Wave Technologies, Inc., a wholly owned subsidiary of Holologic, Inc.

Disclosure: Presented in part at the American Society of Anesthesiologists Annual Meeting, Chicago, Illinois, October 14-18, 2006, and in part at the 9th International Meeting on Human Genome Variation and Complex Genome Analysis, Sitges, Spain, September 6-8, 2007. 
enetic variations conferring heightened risk before, during, and after surgery may fail to manifest phenotypes in the absence of drug exposure or surgical stress. However, genetic polymorphisms are readily detectable by DNA-based methods in advance of surgery, and their consequences may thereby be avoided through selection of alternate interventions. ${ }^{1}$ To determine the allele frequencies of polymorphisms of perioperative interest, and to test the capacity of a novel genotyping platform designed for perioperative applications, microtiter plates were configured for genotyping by structure-specific cleavage of oligonucleotide probes. Polymorphisms in DNA samples from 450 participants undergoing general anesthesia and surgery at an academic suburban hospital, an academic urban Veteran's Affairs hospital and a rural multi-specialty clinic were tested in duplicate for 48 alleles in 22 genes. Discordant results were resolved by replicate testing or by direct DNA sequencing.

\section{MATERIAL AND METHODS Human Participants}

Institutional Review

Investigations were carried out with the approval of the Institutional Review Boards of the University of Wisconsin School of Medicine and Public Health (Madison, WI), the Medical College of Wisconsin and the Zablocki Veteran's Administration Medical Center (Milwaukee, WI), and Marshfield Clinic (Marshfield, WI). Written informed consent was obtained from all participants. All patient samples were de-identified for patient information and assigned unique identification numbers prior to transfer to Third Wave Technologies, Inc. (Madison, WI).

\section{Protocol}

Two hundred participants at the University of Wisconsin, 150 participants at Marshfield Clinic, and 100 participants at the Medical College of Wisconsin Zablocki Veteran's Administration Medical Center provided informed consent and a blood sample for DNA isolation in advance anesthesia. Participants were not recruited on the basis of type of anesthesia or surgery, gender, age, health, outcome or other attribute, and protected health information was not recorded. The DNA stocks were divided at each of the three test centers, and duplicate samples were sent to a reference laboratory at Third Wave Technologies, Inc. in order that each assay on each DNA template would be replicated at the test center of its origin and at the reference laboratory of the manufacturer (figure 1).

A comparison of genotypes at each locus for each patient observed at the test center of origin and at the reference laboratory yielded one of four potential results: (1) the results were concordant, (2) the results were discordant, (3) one or both of the genotypes exhibited a signal intensity below the threshold for accurate interpretation (low signal), (4) or one or both of the genotypes exhibited an equivocal ratio of signal intensities (see below) precluding discrimination of a

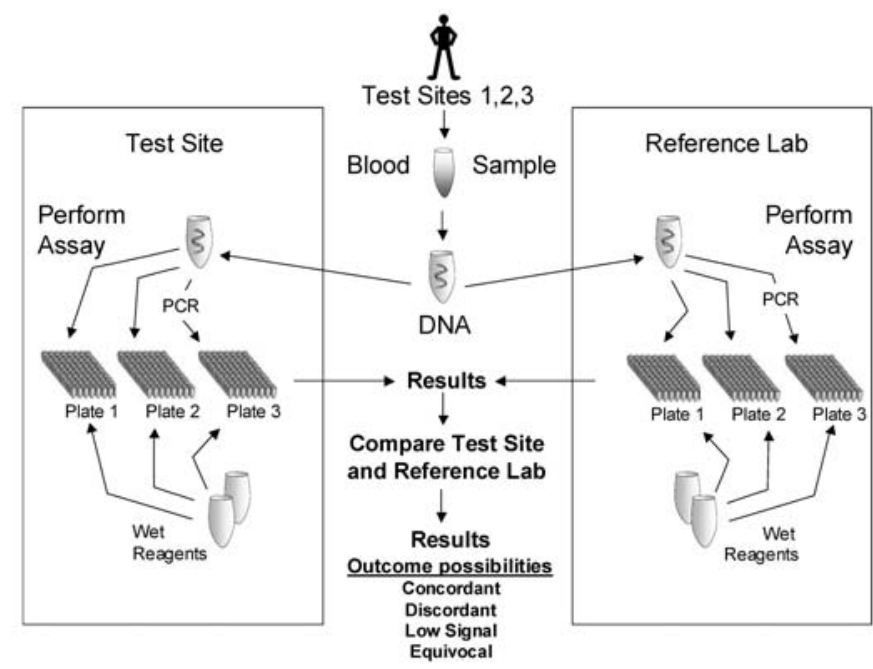

Figure 1. Experimental design and flow chart of samples and data. Genomic DNA was isolated from 450 participants undergoing anesthesia and surgery at three test centers. The samples were genotyped at each of the test centers using panels of structure-specific cleavage of oligonucleotide probes configured for perioperative use. All genotypes were replicated at the manufacturer's reference laboratory, and data were scored for analytical validity (signal intensity, proportion of equivocal results) and concordance between the test center and reference laboratory results.

wild-type or mutant genotype from a heterozygote genotype. Samples yielding discordant genotypes between a template at the reference laboratory and a test center template were re-run side-by-side at the reference laboratory with a second $20 \mathrm{ng} / \mu \mathrm{L}$ aliquot of the discordant DNA stock forwarded from the test center to the reference laboratory. When low signal or equivocal results for a given allele in a given patient were observed at one of the three test centers, a second aliquot of the $20 \mathrm{ng} / \mu \mathrm{L}$ DNA stock was forwarded to the reference laboratory to be re-analyzed. When a low signal or equivocal result was observed on the reference laboratory stock only, it was repeated there. If the low signal, equivocal, or discordant results were not resolved after the first repeat test, the patient's DNA templates were bi-directionally sequenced in the regions flanking each polymorphism of interest.

\section{DNA Isolation and Quantification}

Four hundred fifty unpaid, adult volunteers were enrolled. Ten milliliters of whole blood samples were obtained and anticoagulated in EDTA when intravenous vascular access was established prior to surgery. Samples were assigned an anonymized code number for all future use. Genomic DNA was prepared from frozen $\left(-20^{\circ} \mathrm{C}\right)$ whole blood samples using the desalting Puregene DNA Isolation kit (Gentra Systems, Minneapolis, MN) according to the manufacturer's instructions. DNA concentrations were quantified using the PicoGreen dsDNA Quantitation Kit (Molecular Probes, Inc., Eugene, OR) according to the manufacturer's instructions. DNA stock solutions were diluted in TE $(10 \mathrm{mM}$ Tris, $0.1 \mathrm{mM}$ 
EDTA pH 8.0) to $20 \mathrm{ng} / \mu \mathrm{L}$ and stored at $4^{\circ} \mathrm{C}$. Undiluted stock solutions were stored at $-20^{\circ} \mathrm{C}$.

\section{Allele Selection}

Alleles were chosen for inclusion in the perioperative genomic profile of the present investigation on the basis of clinical validity, i.e., mutant genotypes that are highly correlated with traits of interest to perioperative caregivers comprising altered drug transport $(A B C)$, and drug metabolism $(B C h E$, $A C E, C Y P 2 C 9, C Y P 2 C 19, C Y P 2 D 6, C Y P 3 A 4, C Y P 3 A 5)$, altered pharmacodynamic effects $(\beta 2 A R, T P M T)$, underlying co-existing disease and complications (F2, F5, F7, MTHFR, $T N F \alpha, T N F \beta, C C R 5, A p o E, H B B, M Y H 7)$, and unique patient identifiers ( $A B O$ and Gender) (table 1). ${ }^{2-59}$ As well, alleles were chosen with inherent clinical utility, i.e., the presence of one or more mutant alleles guides the caregiver in the selection of alternative drugs, dosages, regimens, techniques or safety steps.

\section{Structure-Specific Cleavage of Oligonucleotide Probes}

Genotyping by structure-specific cleavage of oligonucleotide probes relies upon the ability of a family of enzymes, termed flap endonucleases, to recognize and cleave highly specific nucleic acid structures ${ }^{60}$ (figure 2). A cleavable structure is formed in vitro through the adjacent hybridization of two synthetic oligonucleotides to a single target DNA molecule. The first "invading" oligonucleotide is designed to be completely complementary to the target sequence with the exception of its terminal 3' base. The second, or "probe" oligonucleotide, comprises a region of complementarity that overlaps the first oligonucleotide by one base, thereby creating a unique structure that is specifically recognized and cleaved by the endonuclease enzyme.

The 5'-end of the probe oligonucleotide includes a non-complementary "flap" sequence. After cleavage, the flap serves as the first oligonucleotide in a second reaction within the same vessel and in contact with the same reagents. In turn, the cleaved flap creates a second overlap structure when bound to its complementary fluorescence resonance energy transfer (FRET) cassette. Subsequent recognition of this structure and cleavage of the cassette by the same flap endonuclease separate the fluorescent dye from its quencher (Eclipse Quencher, Epoch Biosciences, Bothell, WA), resulting in the generation of a detectable fluorescent signal.

Signal amplification occurs during both steps of the cleavage reaction. The probe oligonucleotide is designed so that its melting temperature when hybridized to the target nucleic acid is close to the reaction temperature. Cycling of the probe on and off its template allows for multiple rounds of cleavage,

\section{INVADER CHEMISTRY}
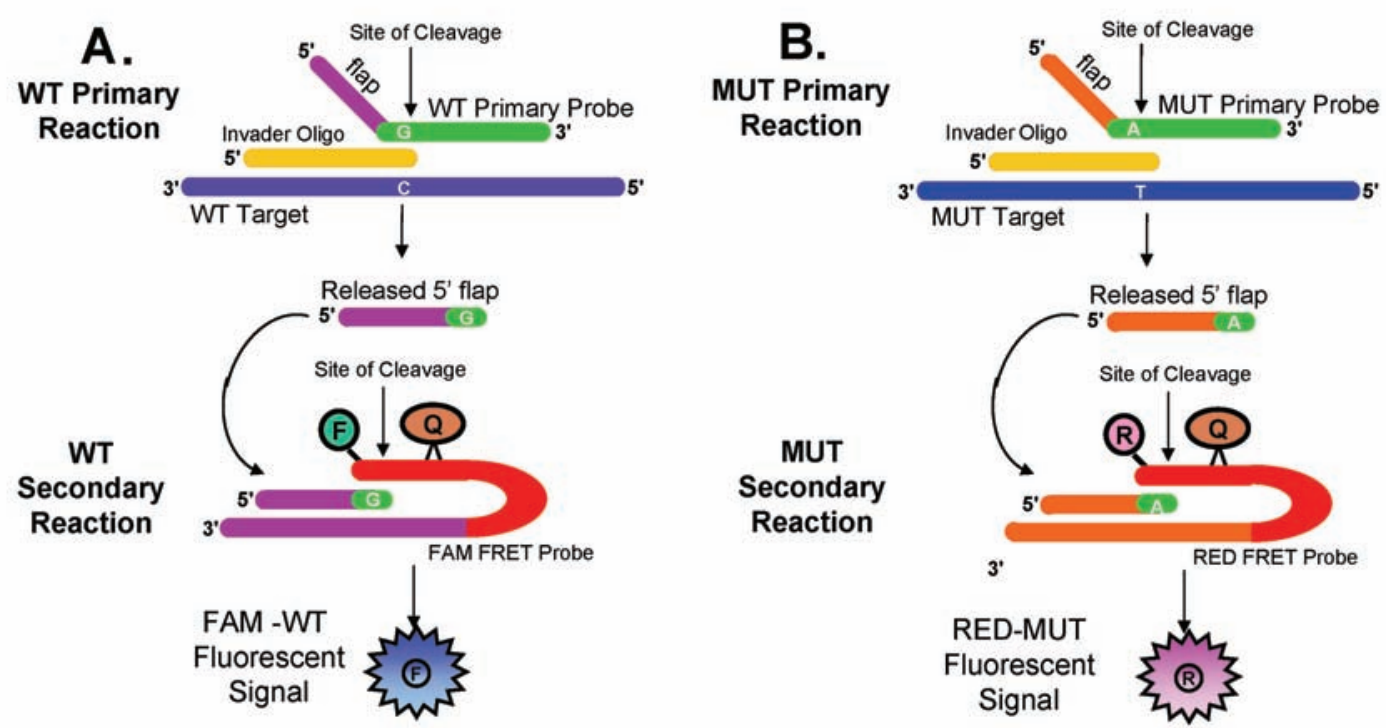

Figure 2. Schematic diagram of structure-specific cleavage of oligonucleotide probes. Recognition and cleavage of specific DNA structures by a member of the FEN-1 family of DNA polymerases enables isothermal probe amplification. The cleavage reaction requires a primary probe complementary in only its $3^{\prime}$ domain to the targeted nucleic acid of interest. $A$ second invading oligonucleotide binds immediately upstream of the first probe with a required overlap of at least one nucleotide to create the structure shown in Figure 2A. Cleavage releases the $5^{\prime}$ domain of the downstream probe, which subsequently acts as a second invading oligonucleotide. Secondary invading oligonucleotides initiate cleavage of fluorescent probes giving rise to a fluorescent signal. The biplex format uses two different discriminatory probes each with a unique 5' flap, and two different fluorescence resonance energy transfer (FRET) cassettes, each with a spectrally distinct fluorophore. The released flaps are configured to bind only to their respective FRET to generate a target-specific signal. Accordingly, the RED cassette responds to the wild-type (WT) probe flap (A), and the FAM cassette responds to the mutant (MT) FAM cassette (B). Both cassettes respond to a heterozygote (HET) template. 
Table 1. Trait, protein name, gene symbol, nucleotide polymorphism, effect of polymorphism and reference number for loci and alleles.

\begin{tabular}{|c|c|c|c|c|c|}
\hline Trait & Protein name & Gene symbol & $\begin{array}{l}\text { Nucleotide } \\
\text { polymorphism }\end{array}$ & Effect of polymorphism & Reference \\
\hline \multicolumn{6}{|c|}{ Pharmacokinetic effects } \\
\hline Drug transport & $\begin{array}{l}\text { ATP-binding cassette } \\
\text { transporter }\end{array}$ & $A B C B 1$ & $\begin{array}{l}\text { G2677T } \\
\text { C3435T }\end{array}$ & $\begin{array}{l}\text { Impaired epithelial drug transport (e.g., } \\
\text { tacrolimus, cyclosporine), anti-emesis }\end{array}$ & $2-4$ \\
\hline \multirow[t]{5}{*}{ Drug metabolism } & Butyrlcholinesterase & $B C H E$ & $\begin{array}{l}\text { A209G } \\
\text { G1615A }\end{array}$ & $\begin{array}{l}\text { Prolonged neuromuscular blockade (e.g., } \\
\text { succinylcholine, mivacurium) }\end{array}$ & $5-7$ \\
\hline & $\begin{array}{l}\text { Cytochrome P450, } \\
\text { family } 2 \text {, subfamily C, } \\
\text { polypeptide } 9\end{array}$ & CYP2C9 & $\begin{array}{l}{ }^{*} 2 \mathrm{C} 416 \mathrm{~T} \\
{ }^{* 3} \mathrm{~A} 1061 \mathrm{C}\end{array}$ & $\begin{array}{l}\text { Impaired drug metabolism (e.g., warfarin, } \\
\text { phenytoin, ibuprofen) }\end{array}$ & $12-16$ \\
\hline & $\begin{array}{l}\text { Cytochrome P450, } \\
\text { family } 2 \text {, subfamily C, } \\
\text { polypeptide } 19\end{array}$ & CYP2C19 & $\begin{array}{l}\text { *2 G681A } \\
\text { *3 G636A }\end{array}$ & $\begin{array}{l}\text { Impaired drug metabolism (e.g., } \\
\text { omeprazole, diazepam, phenytoin } \\
\text { emergence from general anesthesia) }\end{array}$ & 17,18 \\
\hline & $\begin{array}{l}\text { Cytochrome P450, } \\
\text { family } 3 \text {, subfamily A, } \\
\text { polypeptide } 4\end{array}$ & CYP3A4 & *1B A-392G & $\begin{array}{l}\text { Impaired drug metabolism (e.g., } \\
\text { acetaminophen, codeine, cyclosporine, } \\
\text { diazepam, midazolam }\end{array}$ & 24 \\
\hline & $\begin{array}{l}\text { Cytochrome P450, } \\
\text { family } 3 \text {, subfamily A, } \\
\text { polypeptide } 5\end{array}$ & CYP3A5 & $\begin{array}{l}\text { *3 G6986A } \\
\text { *6 A14690G }\end{array}$ & $\begin{array}{l}\text { Impaired drug metabolism } \\
\text { (e.g., benzodiazepines, tacrolimus) }\end{array}$ & $25-27$ \\
\hline & $\begin{array}{l}\text { Thiopurine S- } \\
\text { methyltransferase }\end{array}$ & TPMT & $\begin{array}{l}\text { *2 G238C } \\
\text { *3B G460A } \\
{ }^{* 3 C ~ A 719 G ~}\end{array}$ & $\begin{array}{l}\text { Drug toxicity and impaired efficacy, } \\
\text { organ rejection (e.g., azathioprine, } \\
\text { 6-mercaptopurine) }\end{array}$ & 31 \\
\hline \multicolumn{6}{|l|}{ Co-existing disease } \\
\hline & $\begin{array}{l}\text { Coagulation factor II } \\
\text { (thrombin) }\end{array}$ & $F 2$ & G20210A & Thrombosis and dysprothrombinemia & 32,33 \\
\hline & $\begin{array}{l}\text { Coagulation factor } V \\
\text { (proaccelerin, labile } \\
\text { factor) }\end{array}$ & F5 & G1691A & $\begin{array}{l}\text { Thrombophilia, activated protein } \mathrm{C} \\
\text { resistance, deep venous thrombosis }\end{array}$ & $34-36$ \\
\hline & Coagulation factor VII & $F 7$ & $\begin{array}{l}\text { G10976T } \\
\text { 5' } 10 b p \text { ins, } \\
\text { NT-323 }\end{array}$ & $\begin{array}{l}\text { Coagulopathy, mortality in } \\
\text { myocardial infarction }\end{array}$ & 37 \\
\hline & $\begin{array}{l}5,10 \text {-methylene- } \\
\text { tetrahydrofolate } \\
\text { reductase (NADPH) }\end{array}$ & MTHFR & $\begin{array}{l}\text { C677T } \\
\text { A1298C }\end{array}$ & $\begin{array}{l}\text { Hyper-homocysteinemia, thrombosis, } \\
\text { nitrous oxide toxicity, thrombophilia }\end{array}$ & 38,39 \\
\hline & $\begin{array}{l}\text { Tumor necrosis factor } \\
\text { (TNF superfamily, } \\
\text { member 2) }\end{array}$ & $T N F-\alpha$ & G-308A & $\begin{array}{l}\text { Inflammatory response after } \\
\text { surgery, outcome in sepsis }\end{array}$ & $40-45$ \\
\hline & $\begin{array}{l}\text { Lymphotoxin- } \alpha \\
\text { (TNF superfamily, } \\
\text { member 1) }\end{array}$ & LTA-TNF- $\beta$ & A252G & Vasopressor use after cardiac surgery & 46 \\
\hline
\end{tabular}




\begin{tabular}{|c|c|c|c|c|c|}
\hline Trait & Protein name & Gene symbol & $\begin{array}{l}\text { Nucleotide } \\
\text { polymorphism }\end{array}$ & Effect of polymorphism & Reference \\
\hline \multicolumn{6}{|c|}{ Co-existing disease (continued) } \\
\hline & $\begin{array}{l}\text { Chemokine (C-C motif) } \\
\text { receptor } 5\end{array}$ & CCR5 (delta32) & delta32 & $\begin{array}{l}\text { Delays HIV progression, improved } \\
\text { response to antiretroviral therapy, } \\
\text { transplant rejection }\end{array}$ & 47,48 \\
\hline & Apolipoprotein E & ApoE & $\begin{array}{l}\text { T388C } \\
\text { C476T }\end{array}$ & $\begin{array}{l}\text { Postoperative cognitive dysfunction, } \\
\text { renal dysfunction }\end{array}$ & $49-53$ \\
\hline & $\begin{array}{l}\text { Myosin, heavy chain } \\
7 \text {, cardiac muscle, } \\
\text { beta }\end{array}$ & MYH7 & G10162A & Familial hypertrophic cardiomyopathy & 55 \\
\hline \multicolumn{6}{|c|}{ Gender } \\
\hline & $\begin{array}{l}\text { Protein kinase, } \\
\text { Y-linked }\end{array}$ & $P R K Y$ & Y chromosome & Sample origin & $57-59$ \\
\hline & $\begin{array}{l}\text { Fructose 6-P, } \\
\text { 2-kinase: fructose } \\
\text { 2,6-bisphosphatase }\end{array}$ & PFKFB1 & X chromosome & & \\
\hline
\end{tabular}

and therefore multiple cleaved flaps are created for each target molecule. Similarly, the flap sequence is designed so that the cleaved flap will cycle on and off of its corresponding FRET cassette under shared reaction conditions so that a single cleaved flap produces multiple fluorescent molecules. The combined effect of both reactions running concurrently leads to exponential fluorescent signal amplification kinetics, rather than DNA template amplification.

The specificity of the endonuclease enzyme for the flap-overlap structures, coupled with the sequence specificity conferred by the first and second oligonucleotides, enables precise discrimination of DNA variation. In the case of a single nucleotide polymorphism, oligonucleotide probe-sets are designed so that the polymorphic base is located at the cleavage site of the first reaction. A mismatch at this site, for example, a wild type probe on a mutant DNA target or a mutant probe on a wild type DNA target, fails to generate the overlap structure recognized by the enzyme. No cleavage occurs and no fluorescent signal is detected. Taking advantage of two fluorescent dyes, FAM (BioGenex, San Ramon, CA) and Redmond Red (Epoch Biosciences), the presence or absence of both wild type and mutant alleles of a given polymorphism may be interrogated simultaneously in a shared reaction. In this biplex format, wild type and mutant assays are performed concurrently in the same reaction vessel. Distinct flap sequences, FRET cassettes, and fluorescent dyes allow segregation of the two reaction pathways, and determination of whether 0,1 or 2 copies of each of the two possible alleles at the locus of interest are present. As well, probe sets may be designed for specific polymorphism detection on both the sense and antisense strands of DNA, enabling third-order redundancy for critical clinical applications.

Optimization of probe design by software guided modification of probe length, composition and modifications permits homogenous reaction conditions including, for example, isothermal incubation temperatures, fixed incubation times, and shared buffer (MOPS, PEG) preservative (PRoClin, Supelco, Inc., Bellefonte, PA), $\mathrm{pH}$ and salt concentrations. In this fashion, multiple otherwise unrelated biplex assays may take place in individual wells of a single microtiter plate. Because reagents of the biplex cleavase reaction tolerate dehydration and are stable under conventional freezer conditions, microtiter plates for specific applications may be manufactured and stored months to years in advance to be activated for use in the future by the addition of template and enzyme. In turn, plates may be designed for use with either genomic DNA (plates 1 and 2), or post-PCR templates (plate 3 ) without loss of resolution. 
Performance of the present perioperative assays required only pipetting steps and 30 minutes or less to prepare the reaction. The reaction mixture for each assay was freshly prepared prior to each use. Once the reaction was initiated, no further manipulation was necessary other than moving the microtiter plate from the incubator to a fluorescence microtiter plate reader for scanning.

\section{Genomic DNA Templates}

Two 96-well microtiter plates (i.e., plates 1 and 2) were configured for direct assays of genomic DNA templates. The 96-well microtiter plates containing dried-down oligonucleotides specific for each assay, FAM and RED FRET probes and reaction buffer, together with reagents used

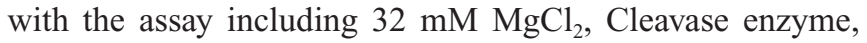
and the No-Target-Blank (NTB) control samples (Third Wave Technologies), were removed from the freezer and thawed to room temperature (table 1, figures 1 and 2). A master mix for each plate was made with $780 \mu \mathrm{L}$ of $32 \mathrm{mM} \mathrm{MgCl}_{2}$ and $120 \mu \mathrm{L}$ Cleavase enzyme. To each well of the two 96-well genomic DNA plates, $7.5 \mu \mathrm{L}$ of the master mix was added. For each plate, $150 \mu \mathrm{L}$ of the NTB sample were placed in the first well of an 8-well microtube strip, and $150 \mu \mathrm{L}$ of purified patient DNA $(20 \mathrm{ng} / \mu \mathrm{L})$ to be tested from 5 patients was placed in the next 5 wells, respectively (figure 3 ). The sample-containing microtube strip (i.e., with two unused wells) was capped, denatured at $95^{\circ} \mathrm{C}$ for 10 minutes in a thermal cycler (MJ Research PTC-100, Watertown, MA), and then cooled to room temperature. To each well of the 96well microtiter plate containing the Cleavase enzyme $/ \mathrm{MgCl}_{2}$ mixture, $7.5 \mu \mathrm{L}$ of the denatured samples were then added using an 8-channel Transferpipette (Rainin, Woburn, MA). Samples were overlaid with $20 \mu \mathrm{L}$ of mineral oil (M-3516, Sigma Chemical Co., St. Louis, MO). The plate was covered with adhesive film (Nunc, Roskilde, Denmark) and briefly spun to bring all reagents to the bottom of the wells. The microtiter plates were then incubated at $63^{\circ} \mathrm{C}$ for 4 hours using a thermal cycler (MJ Research PTC-100) for single plates, or an incubation chamber (St. John's Associates Biotherm Bio-Oven III, Beltsville, MD) for simultaneous incubation of multiple plates.

\section{PCR Templates}

One 96-well microtiter plate (i.e., plate 3) was configured for assays which use amplified DNA as the target template. Because of the presence of a pseudogene at the CYP2D6 locus, templates for CYP2D6 analysis were first amplified by PCR on the microtiter plate, thereby excluding contributions from the pseudogene sequence prior to structure-specific cleavage. The remaining alleles assayed on the PCR plate were included for conservation of reagents and efficiency. PCR primer sequences may be found in table 2 . PCR was performed with $80 \mathrm{ng}$ of genomic DNA (i.e., $4 \mu \mathrm{L}$ of $20 \mathrm{ng} / \mu \mathrm{L}$ ), $4 \mu \mathrm{L}$ of a 1 $\mu \mathrm{M}$ multiplex forward and reverse primer mix for each allele

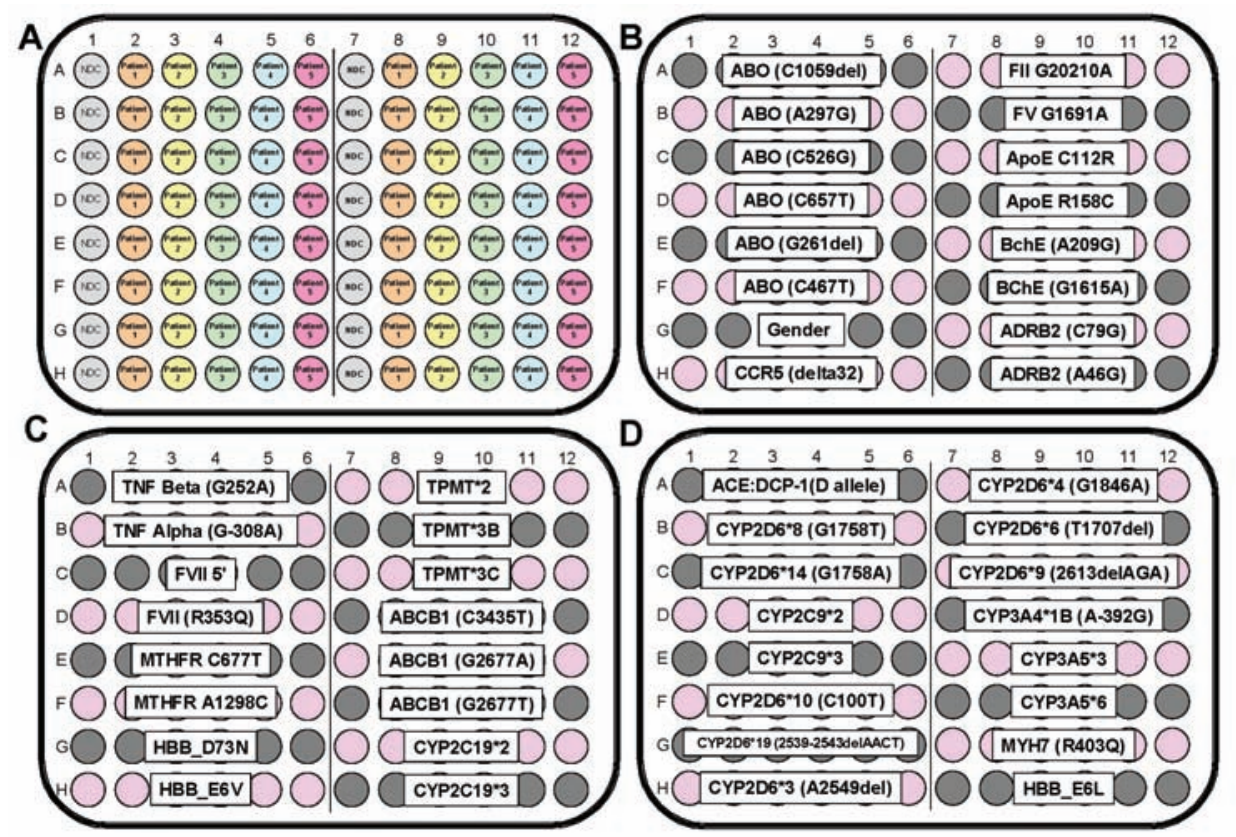

Figure 3. Schematic diagram of platform layout on microtiter plates. The 3 dry-down 96 -well microtiter plates were configured to test 5 patients for 16 alleles on each plate (A-D). The reagents for each assay were arrayed in six sequential wells on one side of the 96-well plate resulting in the first set of 8 alleles on one-half of the plate (A1 to H6), and the second set of 8 alleles on the opposite half of the plate (A7 to H12). Five patient samples and one no template blank (NTB) sample were placed in columns 1-6 and columns 7-12, respectively. This configuration of the samples positioned the DNA from the same patient in columns 2 and 8, 3 and 9, 4 and 10, 5 and 11, and 6 and 12. Thus, each patient was tested for 16 alleles on each of the 3 plates for a total of 48 alleles per patient, with 32 assays performed on genomic DNA templates and 16 assays performed on post-PCR amplicons per patient. 
Table 2. Primers for PCR templates.

\begin{tabular}{ll}
\hline Assay & PCR Primers \\
\hline CYP2C9*2 (C430T) & F: GGA GGA TGG AAA ACA GAG ACT TA \\
& R: GTA GTC CAG TAA GGT CAG TGA TAT G \\
CYP2C9*3 (A1075C) & F: ACA CAT TTG TGC ATC TGT AAC CA \\
& R: TGA TAC TAT GAA TTT GGG GAC TTC G \\
CYP2D6 exons 1,2 & F: AAG GCT TTG CAG GCT TCA \\
& R: GCT CGG ACT ACG GTC ATCA \\
CYP2D6 exons 3,4 & F: TGG AAT CCG GTG TCG AAG \\
& R: GGA GAA ACC TAA AAT CGA AAT CTCT G \\
CYP2D6 exons 5,6 & F: TCT GGG CAA GGA GAG AGG \\
& R: GGC CCC TGC ACT GTT C \\
ACE (DCP-1 D allele) F: CTG GAG ACC ACT CCC ATC CCT TCT & R: GAT GTG GCC ATC ACA TTC GTC AGAT \\
CYP3A5*3 (G6986A) & F: ATT ATG GAG AGT GGC ATA GGA G \\
& R: GGA GTT GAC CTT CAT ACG TT \\
CYP3A5* (A14690G) & F: CCC TTG AAA TTA GAC ACG CA \\
& R: GAA TGT ACA AAA TCA CCA ACT ACTC \\
CYP3A4*1B (A-392G) F: ATT TTG TाT GTC ATG CAA TCC ATT CA & R: CTA TIT TCC TGT CAT TAT GAT TCC CAA A \\
HBB G19A & F: CCA GTT TCT ATT GGT CCT CTT AAA \\
R: CAG GGC AGA GCC ATC TA \\
FYH7 G10162A & F: GTT GTT GGG AAG AGT GAA CTT \\
& R: CAA CTT TGC TAC TTG CCT TTT C \\
\hline
\end{tabular}

F, forward; R, reverse.

(Third Wave Technologies) at $0.2 \mu \mathrm{M}$ final concentration for each primer, 3.2 $\mu \mathrm{L}$ of $1.25 \mathrm{mM}$ dNTPs (Roche, Nutley, NJ), $4 \mathrm{U}(0.8 \mu \mathrm{L})$ of $5 \mathrm{U} / \mu \mathrm{L} \mathrm{Taq}$ polymerase for each reaction (Invitrogen, Carlsbad, CA), $2 \mu \mathrm{L}$ of $10 \mathrm{X}$ amplification buffer (Third Wave Technologies), and $6 \mu \mathrm{L}$ of purified, sterile water for a total of $20 \mu \mathrm{L}$ reaction volume.

The cycling parameters for amplification were: denaturation at $95^{\circ} \mathrm{C}$ for 5 minutes followed by 20 cycles consisting of denaturation at $94^{\circ} \mathrm{C}$ for 30 seconds, annealing at $55^{\circ} \mathrm{C}$ for 1.5 minutes, and extension at $72^{\circ} \mathrm{C}$ for 2.5 minutes, with a final extension at $72^{\circ} \mathrm{C}$ for 10 minutes. The reaction was then held at $99^{\circ} \mathrm{C}$ for 10 minutes to heat deactivate the $\mathrm{Taq}$ polymerase. Samples were diluted 1:50 with TE using $10 \mu \mathrm{L}$ PCR product and $490 \mu \mathrm{L} \mathrm{TE}$ and stored at $4^{\circ} \mathrm{C}$ until use. The Cleavase procedure for the PCR template-microtiter plate 3 assay was similar to that using a genomic template; however, the amplified templates did not require denaturation, and an incubation time of 30 minutes at $63^{\circ} \mathrm{C}$ was sufficient to complete the reaction.

\section{Microtiter Plate Configuration}

The 3 dry-down 96-well microtiter plates were configured to test 5 patients for 16 alleles on each plate (figure 3 ). The reagents for each assay were arrayed in six sequential wells on one side of the 96-well plate, resulting in the first set of 8 alleles on one-half of the plate (A1 to H6) and the second set of 8 alleles on the opposite half of the plate (A7 to H12). Five patient samples and one NTB sample were placed in columns
1-6 and columns 7-12, respectively. This configuration of the samples positioned the DNA from the same patient in columns 2 and 8,3 and 9, 4 and 10,5 and 11, and 6 and 12. Thus, each patient was tested for 16 alleles on each of the 3 plates for a total of 48 alleles per patient, with 32 assays performed on genomic DNA templates and 16 assays performed on post-PCR amplicons per patient.

\section{Data Acquisition}

After the 4-hour $63^{\circ} \mathrm{C}$ incubation for genomic templates and the 30 minute incubation at $63^{\circ} \mathrm{C}$ for the amplified templates were complete, the plates were equilibrated to room temperature and scanned in either a CytoFluor Multi-Well Plate Reader, Series 4000 (PerSeptive Biosystems, Framingham, MA), or a Tecan-GENios Plate Reader (Durham, NC). Two scans were made sequentially, one for FAM dye (excitation 485/20 $\mathrm{nm}$, emission $530 / 25 \mathrm{~nm}$ ), and one for Redmond Red dye (excitation 560/20 nm, emission 620/40 nm (for the CytoFluor reader) or $612 / 10 \mathrm{~nm}$ (for the Tecan-GENios plate reader).

\section{DNA Sequencing}

Unresolved discordant, low signal, and equivocal samples were bi-directionally sequenced. For the allele of interest, both the test center and reference laboratory stocks were sequenced. Samples to be sequenced were first amplified using Amplitaq Gold with GeneAmp PCR reagents (Applied Biosystems, Foster City, CA). The total $50 \mu \mathrm{L}$ PCR reaction mixture consisted of $2 \mu \mathrm{L}$ of $10 \mathrm{X}$ PCR buffer II, $4 \mu \mathrm{L}$ of $10 \mathrm{mM}$ dNTPs at a final concentration of $200 \mu \mathrm{M}$ each, $0.5 \mu \mathrm{L}$ (2.5 U/ rxn) Amplitaq Gold, $1 \mu \mathrm{L}$ of the forward and reverse primers $(20 \mu \mathrm{M})$ (table 3), yielding a final primer concentration of 0.4 $\mu \mathrm{M}, 3$ to $6 \mu \mathrm{L}$ of $25 \mathrm{mM} \mathrm{MgCl}_{2}$ for a final concentration of 1.5 to $3.0 \mathrm{mM}$, respectively as required for each reaction, 5 $\mu \mathrm{L}$ of DNA $(20 \mathrm{ng} / \mu \mathrm{L})$ for a final concentration of $100 \mathrm{ng} /$ $\mu \mathrm{L}$, and $\mathrm{ddH}_{2} \mathrm{O}$ to bring the reaction volume to $50 \mu \mathrm{L}$. Each PCR reaction was amplified with a $95^{\circ} \mathrm{C} \mathrm{Taq}$ activation step for 10 minutes, then 35 cycles of denaturing at $95^{\circ} \mathrm{C}$ for 1 minute, annealing temperature listed in table 3 for 1 minute, and elongation at $72^{\circ} \mathrm{C}$ for 1 minute, with a final elongation at $72^{\circ} \mathrm{C}$ for 10 minutes. After PCR amplification, $5 \mu \mathrm{L}$ of the product was treated with $2 \mu \mathrm{L}$ of ExoSAP-IT (USB, Cleveland, $\mathrm{OH}$ ) and incubated at $37^{\circ} \mathrm{C}$ for 15 minutes to remove unused dNTPs and primers. The enzyme was heat deactivated at $80^{\circ} \mathrm{C}$ for 15 minutes.

The sequencing reaction consisted of $1 \mu \mathrm{L}$ of the ExoSAP-IT treated amplified product, $11.75 \mu \mathrm{L} \mathrm{ddH}_{2} 0,2 \mu \mathrm{L}$ BigDye (Applied Biosystems), $4 \mu \mathrm{L}$ of $2.5 \mathrm{X}$ BigDye buffer, $1 \mu \mathrm{L}$ DMSO (Sigma Chemical Co.), and $0.25 \mu \mathrm{L}$ of $20 \mu \mathrm{M}$ primer (20 $\mu \mathrm{L}$ total reaction volume). A separate reaction mix was made for each primer to bi-directionally sequence each sample. The BigDye sequencing reaction was performed using one cycle at $96^{\circ} \mathrm{C}$ for 3 minutes, 35 cycles at $96^{\circ} \mathrm{C}$ for 10 seconds and $58^{\circ} \mathrm{C}$ for 2 minutes, and one cycle of $72^{\circ} \mathrm{C}$ for 2 minutes. The sequencing products were cleaned (i.e., for removal of dye terminators, dNTPs, and primers) with CleanSEQ magnetic beads (Agencourt, Beverly, MA) according to the 
manufacturer's specifications. The products were directly sequenced using an Applied Biosystems 3730xl automated sequencing instrument at the DNA Sequence Laboratory in the UW Biotechnology Center, Madison, WI.

\section{Data Analysis}

Fluorescent intensity data were imported from the plate reader into a Microsoft Excel 2000 worksheet for analytical calculations on the raw data to determine genotypes. The fluorescent emission data were analyzed using 3 parameters: (1) FAM dye fold over zero (FFOZ), (2) RED dye fold over zero (RFOZ), and (3) fold over zero (FOZ) ratio. The FOZ criteria and FOZ ratio specifications were predetermined by testing each assay against a panel of 120 human genomic DNA control samples of varying genotypes and ancestral origins. For a given assay, FOZ and FOZ ratio criteria were established by tolerance testing the control templates with multiple variables including DNA extraction methods, DNA concentrations, lot-to-lot variation in otherwise identical DNA templates, and alternate instrumentation. Lower specification limits for FOZ are set such that the value exceeds the signal to noise ratio by a significant margin, i.e., by a factor of 2.5 or greater. FOZ ratio thresholds are established by statistical analysis of the tolerance test data. For example, the heterozygote FOZ ratio threshold is set at approximately 3 standard deviations from the mean to typically fall within a range of 0.5 to 2.0, with mutant FOZ ratio thresholds at 0.2 or less, and wild-type FOZ ratio thresholds at 5.0 or greater. The FFOZ of a sample tested for each allele was obtained by dividing the observed raw FAM signal of the patient sample by the raw FAM signal from the NTB for that assay. The RFOZ was calculated in the same manner. Assays for each allele were assigned a specific minimum FOZ value for homozygous normal (or wild-type), heterozygous, and homozygous mutant allele FOZ determination (table 4).

If the FOZ criteria were not met, then the sample was designated low signal. For example, all assays on plate 1 have a

Table 3. PCR and sequencing primers and conditions.

\begin{tabular}{|c|c|c|c|c|}
\hline Assay & PCR and Sequencing Primers & $\begin{array}{l}\text { Annealing } \\
\text { Temp. }{ }^{\circ} \mathrm{C}\end{array}$ & $\begin{array}{l}\mathrm{mM} \\
\mathrm{MgCl}_{2}\end{array}$ & $\begin{array}{l}\text { Primer } \\
\text { Reference }\end{array}$ \\
\hline$A B C B 1(\mathrm{G} 2677 \mathrm{~A})$ & $\begin{array}{l}\text { F: CTG ATA AAA TAA TGA ATA TAG TCT C } \\
\text { R: TAG AGC ATA GTA AGC AGT AGG }\end{array}$ & 53.0 & 2.5 & 1 \\
\hline ABCB1 (G2677T) & $\begin{array}{l}\text { F: CTG ATA AAA TAA TGA ATA TAG TCT C } \\
\text { R: TAG AGC ATA GTA AGC AGT AGG }\end{array}$ & 53.0 & 2.5 & 1 \\
\hline ABCB1 (C3435T) & $\begin{array}{l}\text { F: TGT TTT CAG CTG CTT GAT GG } \\
\text { R: AAG GCA TGT ATG TTG GCC TC }\end{array}$ & 62.0 & 1.5 & 2 \\
\hline$B C h E(G 1615 A)$ & $\begin{array}{l}\text { F: CTG TAC TGT GTA GTT AGA GA } \\
\text { R: GAG GAA TCA ATA TTA TCC TTC TGG C }\end{array}$ & 53.0 & 1.5 & UW \\
\hline CYP2C19*2 (G681A) & $\begin{array}{l}\text { F: AAT TAC AAC CAG AGC TTG GC } \\
\text { R: TAT CAC TIT CCA TAA AAG CAA G }\end{array}$ & 57.0 & 2.5 & 3 \\
\hline CYP2D6*3 (A2549del) & $\begin{array}{l}\text { F: GCT GGG GCC TGA GAC TT } \\
\text { R: CAC TCT CAC CTT CTC CA }\end{array}$ & 55.5 & 1.5 & $\begin{array}{l}\mathrm{F}=4 \\
\mathrm{R}=\mathrm{TWT}\end{array}$ \\
\hline CYP2D6*4 (G1846A) & $\begin{array}{l}\text { F: CCT GGG CAA GAA GTC GCT GGA CCA G } \\
\text { R: GAG ACT CCT CGG TCT CTC G }\end{array}$ & 62.0 & 2.0 & 4 \\
\hline CYP2D6*6 (T1707del) & $\begin{array}{l}\text { F: CCT GGG CAA GAA GTC GCT GGA CCA G } \\
\text { R: GAG ACT CCT CGG TCT CTC G }\end{array}$ & 62.0 & 2.0 & 4 \\
\hline CYP2D6*9 (2613delAGA) & $\begin{array}{l}\text { F: CGT CCT CCT GCA T } \\
\text { R: TGC ACT GTT TCC CAG }\end{array}$ & 55.5 & 1.5 & TWT \\
\hline CYP2D6*10 (C100T) & $\begin{array}{l}\text { F: GGT AGT GAG GCA GGT } \\
\text { R: GCT TCT GGT AGG GGA G }\end{array}$ & 57.5 & 1.5 & TWT \\
\hline $\begin{array}{l}\text { CYP2D6*19 } \\
\text { (2539-2543deIAACT) }\end{array}$ & $\begin{array}{l}\text { F: GCT GGG GCC TGA GAC TT } \\
\text { R: CAC TCT CAC CTT CTC CA }\end{array}$ & 55.5 & 1.5 & $\begin{array}{l}\mathrm{F}=4 \\
\mathrm{R}=\mathrm{TWT}\end{array}$ \\
\hline CYP3A4*1B (A-392G) & $\begin{array}{l}\text { F: CTC TAA GAG AAG GCT CTG TCT G } \\
\text { R: GCT GGG CTA TGT GCA TG }\end{array}$ & 57.5 & 1.5 & UW \\
\hline CYP3A5*3 (G6986A) & $\begin{array}{l}\text { F: CAT CAG TTA GTA GAC AGA TGA } \\
\text { R: GGT CCA AAC AGG GAA GAA ATA }\end{array}$ & 58.4 & 1.5 & 5 \\
\hline MTHFR (C677T) & $\begin{array}{l}\text { F: GGT GGA GGC CAG CCT CTC CTG } \\
\text { R: GCG GTG AGA GTG GGG TGG AGG G }\end{array}$ & 69.0 & 2.5 & UW \\
\hline$T N F-\beta(\mathrm{A} 252 \mathrm{G})$ & $\begin{array}{l}\text { F: CCG TGC TTC GTG CTT TGG ACT A } \\
\text { R: AGA GGG GTG GAT GCT TGG GTT C }\end{array}$ & 61.5 & 1.5 & 6 \\
\hline $\begin{array}{l}\text { Gender } \\
(P R K Y \text { and } P F K B 1)\end{array}$ & $\begin{array}{l}\text { F: CTG ATG GTT GGC CTC AAG CCT GTG } \\
\text { R: TAA AGA GAT TCA TTA ACT TGA CTG }\end{array}$ & 65.0 & 3.0 & 7 \\
\hline
\end{tabular}

F, forward; R, reverse; TWT, Third Wave Technologies; UW, University of Wisconsin-Madison. 
Table 4. Fold over zero (FOZ) and FOZ ratio criteria.

\begin{tabular}{|c|c|c|c|c|c|c|c|c|}
\hline & $\begin{array}{c}\text { Normal } \\
\text { Min_Ratio }\end{array}$ & $\begin{array}{l}\text { Normal } \\
\text { FOZ_Min }\end{array}$ & $\begin{array}{c}\text { Het } \\
\text { Min_Ratio }\end{array}$ & $\begin{array}{c}\text { Het } \\
\text { Max_Ratio }\end{array}$ & $\begin{array}{c}\text { Het } \\
\text { FFOZZ_Min }\end{array}$ & $\begin{array}{c}\text { Het } \\
\text { RFOZ_Min }\end{array}$ & $\begin{array}{c}\text { Mutant } \\
\text { Max_Ratio }\end{array}$ & $\begin{array}{c}\text { Mutant } \\
\text { Min_FOZ }\end{array}$ \\
\hline Plate 1 & 5.00 & 1.50 & 0.40 & 2.50 & 1.50 & 1.50 & 0.20 & 1.50 \\
\hline Plate 2 & 5.00 & 1.50 & 0.40 & 2.50 & 1.50 & 1.50 & 0.20 & 1.50 \\
\hline Plate 3 & 4.90 & 1.50 & 0.40 & 2.50 & 1.50 & 1.50 & 0.21 & 1.50 \\
\hline Plate 3 & 3.50 & 1.50 & 0.40 & 2.50 & 1.50 & 1.50 & 0.28 & 1.50 \\
\hline HBB_E6L & & & & & & & & \\
\hline
\end{tabular}

FFOZ, FAM dye fold over zero; Het, heterozygote; Max, maximum; Min, minimum; RFOZ, RED dye fold over zero.

reactive-minimum FAM wild-type probe $\mathrm{FOZ}$ of at least 1.5 required for a wild-type homozygous genotype assignment, and a minimum RED mutant probe FOZ of at least 1.5 for a mutant homozygous genotype assignment (table 4). For the same plate, a heterozygote assignment requires both the FAM and RED FOZ values to be at a minimum of 1.5 . If the FOZ values for a given sample and a given assay met the minimum FOZ allele criteria for wild-type, heterozygote, or mutant genotype, then the sample was considered valid. Validity criteria for each plate apply to all assays on that plate, except for the HBB G19A assay on plate 3, which shares identical FOZ criteria as all other assays on plate 3, but uses an independent FOZ ratio criterion based on specific performance characteristics of the assay (see below).

For samples meeting FOZ signal threshold criteria, the FOZ ratio was calculated to determine the final genotype designation. The FOZ ratio was calculated from the raw wildtype and mutant FOZ scores using the formula:

FOZ ratio $=$ (wild type FOZ-1) $/($ mutant FOZ-1)

If the calculated FOZ- 1 was $<0$, its value was assigned as 0.10 in order that the FOZ ratio cannot be zero. For a given sample and assay, if the FOZ values met one of the three minimum FOZ allele criteria for wild-type, heterozygote, or mutant, and also met the FOZ ratio range criteria for wild-type, heterozygote, or mutant, then the sample was considered valid and the genotype was properly assigned. If the FOZ validity criteria were met, but the FOZ ratio criteria failed to fall within the specification range, then the sample was considered equivocal. For all wild-type genotype calls, regardless of allele, the ratio FOZ must be $\geq 5.0$. Regardless of the allele in question, for all heterozygote genotype designations the FOZ ratio must be $\geq 0.4$ and $\leq 2.5$. For all mutant genotypes, the FOZ ratio must be $\leq 0.20$. The only exception to the FOZ ratio specification was assay HBB_E6L with wild-type FOZ ratio $>3.5$ and mutant FOZ ratio $<0.28$. For this assay, the wild-type and mutant probes exhibit cross reactivity, and specifications were widened to assign the correct designation.

\section{RESULTS}

\section{Analytical Performance}

Of 43,200 genotypes, 42,872 assays (99.24\%) were both valid and unequivocal on the first testing. Of the remainder, 164 assays $(0.38 \%)$ were low signal with 126 resolved (i.e., met FOZ validity criteria and FOZ ratio specifications) by retesting. Thirty-eight assays $(0.09 \%)$ remained low signal after retesting, and the genotypes were resolved by direct sequencing. Similarly, 164 of the 43,200 assays $(0.38 \%)$ were valid but did not meet FOZ ratio specifications and were designated equivocal, with 148 resolved by retesting. Of the 16 remaining equivocal assays $(0.04 \%), 15$ were also resolved by direct sequencing. In all, after retesting, 43,145 assays $(99.87 \%)$ were both valid and unequivocal with the structure-specific genotyping, 53 low signal and equivocal assays $(0.123 \%)$ were resolved by sequencing, and 2 assays $(0.005 \%)$ were unresolved.

On first testing, 21,542 of 21,600 (99.73\%) pair-wise comparisons of valid and unequivocal assays for the same allele on the same DNA template were concordant between the test center and the reference laboratory. Fifty-five of the remaining 58 valid and unequivocal discordant comparisons became concordant upon retesting. Three pair-wise discordant comparisons were not resolved using the structure-specific technology. After direct sequencing, 2 of the 3 pairs were resolved by direct sequencing. A low signal/heterozygote pair was found by sequencing to be a mutant/mutant genotype, an equivocal/normal pair was found by sequencing to be a mutant/mutant genotype, and an equivocal/equivocal pair was unresolved by sequencing. In one of the two samples where a genotype was determined $(A B O \mathrm{~A} 297 \mathrm{G})$, bi-directional sequencing revealed a deletion 5 ' to the polymorphism of interest. In the other $\left(C Y P 2 D 6^{*} 10[\mathrm{C} 100 \mathrm{~T}]\right)$, a coincident copy number polymorphism led to increased signal intensity of the mutant allele due to increased copy number. In all, after all testing, 21,597 pair comparisons (99.99\%) were valid and concordant for the same allele on the same DNA template between the test center and the reference laboratory. Two pairs $(0.009 \%)$ were resolved by sequencing, and one pair $(0.005 \%)$ was unresolved.

\section{Allele Frequency}

The observed allele frequencies for 38 of the 48 polymorphisms comprising the present perioperative genomic profile were in close accord with values published by others in comparable populations (table 5). ${ }^{61-75}$ Divergences between observed and published allele frequencies were apparent in genotypes underlying expression of $\mathrm{ABO}$ blood groups and hepatic drug metabolism. For example, the overall incidence of CYP2C19*2 and $C Y P 2 D 6^{*} 4$ in the present sample were nearly double that reported by others, whereas the allele frequencies of CYP $2 D 6^{*} 3$, and $C Y P 2 D 6^{*} 9$ were six-fold and ten-fold greater, 


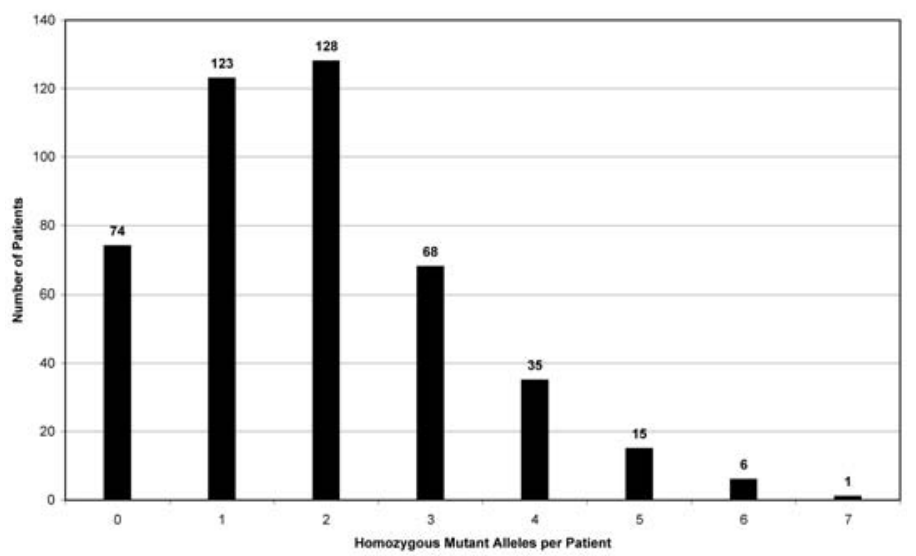

Figure 4. Homozygous mutant alleles per patient. After withdrawing 8 polymorphisms in non-pathogenic genes from analysis (i.e., 6 alleles in the $\mathrm{ABO}$ blood group and the 2 gender-specific alleles), 376 of 450 patients were found to be homozygous for mutant alleles at 1 or more of 40 loci, with a mode of 2 mutant homozygous loci per patient.

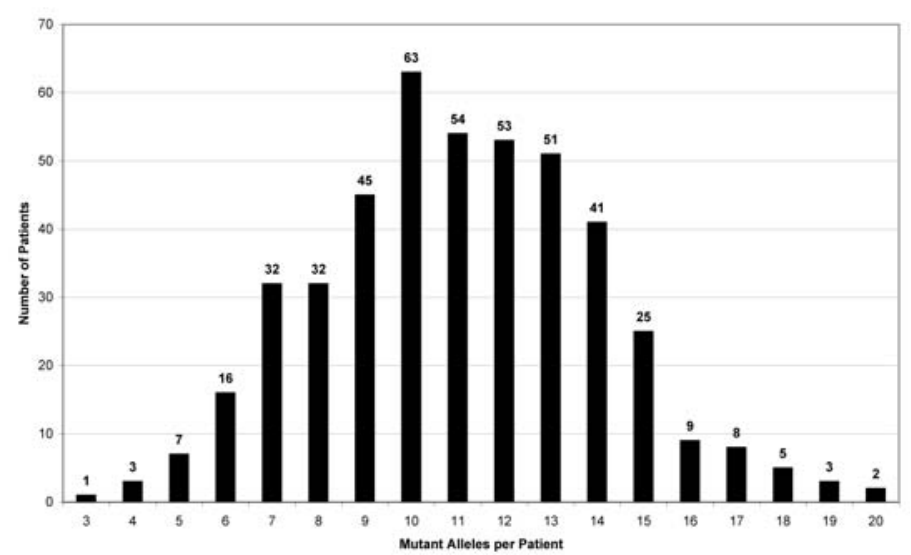

Figure 5. Total mutant alleles per patient. A mode of 10 mutant alleles in aggregate (i.e., the sum of homozygous plus heterozygous mutant polymorphisms) were observed per patient. respectively. Conversely, $T P M T^{*} 3 C$ was found to be roughly half as common in the population under investigation compared to prior descriptions. On the basis of these results, it is not possible to determine if the allele frequencies we observed at these loci differ from prior reports on the basis of population stratification, founder effects, or non-random sampling. Nevertheless, these differences underscore the potential benefit of tailoring selection of the components of a perioperative genomic profile to its intended target population.

\section{Polymorphisms per Patient}

After withdrawing 8 polymorphisms in non-pathogenic genes from analysis (i.e., 6 alleles in the ABO blood group and the 2 gender-specific alleles), 376 of 450 patients were found to be homozygous for mutant alleles at 1 or more of 40 loci, with a mode of 2 mutant homozygous loci per patient (figure 4). A mode of 10 mutant alleles in aggregate (i.e., the sum of homozygous plus heterozygous mutant polymorphisms) was observed per patient (figure 5). No mutant $C Y P 2 D 6^{*} 8$, CYP2D6*14, CYP2D6*19, HBB (G220A) or MYH7 alleles were detected in keeping with their very low overall frequency. A $>10 \%$ incidence of homozygosity for $A B C B 1, A C E$, $A D B R B 2, M T H F R$, and TNF $\beta$ mutant alleles was observed, again in close accord with published accounts.

\section{DISCUSSION}

The present report describes the first genomic profile prospectively designed, assembled, and tested in surgical patients for use by perioperative caregivers. We found that the majority of patients were homozygous for mutant alleles at 1 or more loci, with a mode of 2 mutant homozygous loci, and a mode of 10 mutant alleles in aggregate observed per patient. Unless the consequences of prior exposure to anesthesia and surgery in the patient or family member are known, it is unlikely that perioperative caregivers would learn of the presence of these mutant alleles without genotyping. In turn, knowledge of non-pathogenic alleles incorporated in the perioperative genomic profiles adds safeguards in prevention of patient misidentification, for example, prior to organ transplantation or transfusion of blood products.

A genotyping method adapted for perioperative use must accurately sort over 3 billion DNA base pairs in each patient to identify differences upon which well-being during surgery and anesthesia depends. Ideally, the method must be equally sensitive to rare and common polymorphisms, to allelic and locus heterogeneity, and to compound and mixed heterozygosity underlying a given trait. The preferred genotyping method must detect polymorphisms equally well in samples from distinct origins (i.e., genomic DNA, RNA-derived complementary DNA, the products of PCR, or whole genome amplification from blood, tissue or cheek swab specimens). The present results indicate that susceptibilities from multiple predisposing genetic conditions can be effectively quantified using a shared genotyping format, i.e., oligonucleotide probes designed for biplex cleavage and detection assembled on a universal platform, i.e., dried-down reagents in 96-well microtiter plates. This format and platform enable homogenous reaction conditions (e.g., identical volumes and concentrations of template and enzyme, and shared incubation duration and temperature) that are suited to the acquisition of highly heterogenous genomic data, e.g., single nucleotide polymorphisms in coding, non-coding and promoter sequences, deletions, and insertions. The technique does not rely on radioisotopes or intercalating dyes, and does not require acrylamide or agarose gels, or dedicated hardware that is costly to purchase and maintain. Because detection of structure-specific cleavage of oligonucleotide probes relies on signal rather than template amplification, it is refractory to contamination by ambient or sample-to-sample contamination, and is sparing of DNA stocks. Moreover, the raw scores and ratios of fluorescent intensity are immediately accessible to the operator and end-user wishing to look beyond computed calculation for quality assurance. 
Table 5. Observed vs published allele frequencies.

\begin{tabular}{|c|c|c|c|c|c|c|}
\hline Genotype & WT \% & Het $\%$ & Mut \% & $\begin{array}{c}\text { Observed allele } \\
\text { frequency (\%) }\end{array}$ & $\begin{array}{l}\text { Published allele } \\
\text { frequency (\%) }\end{array}$ & Reference \\
\hline$A B C B 1$ (G2677T) & 32.4 & 48.7 & 18.9 & 43.2 & 46.0 & 61 \\
\hline$A B C B 1$ (C3435T) & 30.0 & 51.1 & 27.1 & 52.7 & 54.0 & 61 \\
\hline BCHE (A209G) & 96.9 & 3.1 & 0.0 & 1.6 & 2.4 & 62 \\
\hline$B C H E(G 1615 A)$ & 63.8 & 33.6 & 2.7 & 19.4 & 18.7 & 62 \\
\hline ACE DCP-1 (D allele) & 22.0 & 51.3 & 26.7 & 52.3 & 44.6 & 63 \\
\hline CYP2C9*2 (C416T) & 78.0 & 20.0 & 2.0 & 12.0 & 15.5 & 64 \\
\hline CYP2C9*3 (A1061C) & 84.0 & 14.9 & 1.1 & 8.6 & 6.9 & 64 \\
\hline CYP2C19*2 (G681A) & 73.3 & 24.9 & 1.8 & 14.2 & 8.0 & 65 \\
\hline CYP2C19*3 (G636A) & 99.3 & 0.4 & 0.2 & 0.4 & 0.0 & 65 \\
\hline CYP2D6*3 (A2549del) & 95.3 & 4.4 & 0.2 & 2.4 & 0.4 & 23 \\
\hline CYP2D6*4 (G1846A) & 63.3 & 30.0 & 6.7 & 21.7 & 13.1 & 23 \\
\hline CYP2D6*6 (T1707del) & 97.6 & 2.4 & 0.0 & 1.2 & 0.4 & 23 \\
\hline CYP2D6*8 (G1758T) & 100.0 & 0.0 & 0.0 & 0.0 & 0.0 & 66 \\
\hline CYP2D6*9 (2613delAGA) & 96.7 & 3.1 & 0.2 & 1.8 & 1.5 & 23 \\
\hline CYP2D6*10 (C100T) & 61.8 & 30.7 & 6.9 & 22.2 & 2.9 & 23 \\
\hline CYP2D6*14 (G1758A) & 100.0 & 0.0 & 0.0 & 0.0 & 0.2 & 23 \\
\hline CYP2D6*19 (2539-2543delAACT) & 100.0 & 0.0 & 0.0 & 0.0 & 0.1 & 67 \\
\hline CYP3A4*1B (A-392G) & 89.6 & 8.7 & 1.8 & 6.1 & 6.5 & 68 \\
\hline CYP3A5*3 (G6986A) & 82.4 & 14.2 & 3.3 & 10.4 & 13.0 & 69 \\
\hline CYP3A5*6 (A14690G) & 79.8 & 16.7 & 3.6 & 11.9 & 9.6 & 69 \\
\hline$A D R B 2(\mathrm{G} 46 \mathrm{~A})$ & 38.7 & 46.0 & 15.3 & 38.3 & 37.8 & 63 \\
\hline ADRB2 (C79G) & 36.7 & 44.4 & 18.9 & 41.1 & 41.0 & 63 \\
\hline 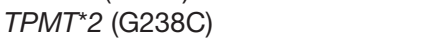 & 99.6 & 0.4 & 0.0 & 0.2 & 0.2 & 70 \\
\hline$T P M T * 3 B(G 460 A)$ & 94.0 & 5.8 & 0.2 & 3.1 & 2.6 & 71 \\
\hline$T^{2} M T^{\star} 3 C$ (A719G) & 92.7 & 7.1 & 0.2 & 3.8 & 7.3 & 71 \\
\hline$F 2(G 20210 A)$ & 97.1 & 2.9 & 0.0 & 1.4 & 1.9 & 63 \\
\hline F5 (G1691A) & 95.1 & 4.7 & 0.2 & 2.6 & 2.5 & 63 \\
\hline F7 (G10976T) & 79.1 & 18.7 & 2.2 & 11.6 & 13.8 & 63 \\
\hline F7 5' (10bp ins, NT-323) & 76.4 & 20.7 & 2.9 & 13.2 & 14.6 & 63 \\
\hline MTHFR (C677T) & 40.0 & 46.7 & 13.3 & 36.7 & 35.3 & 63 \\
\hline MTHFR (A1298C) & 49.1 & 41.6 & 9.3 & 30.1 & 32.4 & 72 \\
\hline TNF Alpha (G-308A) & 68.2 & 29.6 & 2.2 & 17.0 & 15.4 & 63 \\
\hline LTA (A252G) & 43.8 & 41.3 & 14.9 & 35.6 & 31.0 & 63 \\
\hline CCR5 (delta32) & 79.6 & 19.6 & 0.9 & 10.7 & 10.9 & 63 \\
\hline ApoE (T388C) & 74.7 & 24.7 & 0.7 & 13.0 & 13.9 & 63 \\
\hline ApoE (C476T) & 84.7 & 14.4 & 0.9 & 8.1 & 8.3 & 63 \\
\hline$H B B(G 220 A)$ & 100.0 & 0.0 & 0.0 & 0.0 & 0.01 & 73 \\
\hline$H B B(G 19 A)$ & 99.8 & 0.2 & 0.0 & 0.1 & 0.01 & 73 \\
\hline HBB (A20T) & 99.6 & 0.4 & 0.0 & 0.2 & 0.05 & 73 \\
\hline MYH7 (G10162A) & 100.0 & 0.0 & 0.0 & 0.0 & 0.0 & 74 \\
\hline$A B O$ (G261del) & 39.3 & 50.7 & 9.8 & 35.1 & 57.2 & 75 \\
\hline$A B O(\mathrm{~A} 297 \mathrm{G})$ & 84.4 & 14.9 & 0.7 & 8.1 & 30.1 & 75 \\
\hline ABO (C467T) & 77.8 & 20.4 & 1.8 & 12.0 & 7.1 & 75 \\
\hline$A B O(\mathrm{C} 526 \mathrm{G})$ & 82.4 & 16.9 & 0.7 & 9.1 & 13.8 & 75 \\
\hline$A B O(\mathrm{C} 657 \mathrm{~T})$ & 18.0 & 46.7 & 35.3 & 58.7 & 12.8 & 75 \\
\hline$A B O$ (C1059del) & 86.2 & 13.1 & 0.7 & 7.2 & 5.6 & 75 \\
\hline Gender (PRKY and PFKFB1) & 0.0 & 0.0 & 0.0 & $\begin{array}{l}200 \text { female } \\
250 \text { male }\end{array}$ & 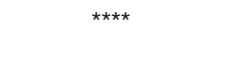 & **** \\
\hline
\end{tabular}

Het, heterozygote; Mut, mutant; WT, wild type; ${ }^{\star \star \star \star}$, not applicable.

Of 43,200 genotypes, 99.24\% were both valid and unequivocal on first testing, rising to $99.87 \%$ after a single replication. These results suggest that systemic factors inherent to the template or assay did not contribute to initial low signal or equivocal designations, but rather point to extrinsic variables amenable to automation, e.g., errors in pipetting, mixing, or data entry. On first testing, $99.73 \%$ of 21,600 comparisons of valid and unequivocal assays for the same allele on the same DNA template were concordant between the test center and a reference laboratory, rising to $99.99 \%$ after a single replication. In 2 of the 3 residual discordant comparisons (i.e., 3 pairs of alleles), a second polymorphism was detected in one of the paired templates that interfered with the probe-set in question. In aggregate, these results using newly designed assays in novel formats and platforms compare well with an overall $0.5 \%$ to $1.0 \%$ rate of genotyping errors using long-established methods. ${ }^{76}$ In no circumstance were skewed results traceable to ambient or sample-to-sample contamination during assay performance despite using allele-specific microtiter plates (i.e., samples from multiple patients on one plate) rather than patient-specific microtiter plates, and manual rather than robotic operating procedures. 
Structure-specific cleavage of oligonucleotide probes is not the only method suitable for perioperative applications. Whereas conventional genotyping techniques, including direct DNA sequencing, restriction fragment length polymorphism analysis, and allele-specific PCR provide sufficient accuracy, they are ill-suited for point-of-care, broad-scale screening because of constraints in ease of use, cost, and scalability. Emerging high through-put approaches including, microarray-based detection (i.e., gene chips), mass spectrometry and whole genome sequencing may be able to rapidly score up to thousands of polymorphisms on a single sample, but routine use in health care is hampered by the need for expensive, single purpose hardware and by inaccuracies in heterozygote detection. Recently, the performance of another Invader platform (i.e., InPlex for cystic fibrosis genotyping on a microfluidics card) was compared with eSensor (Osmetech Molecular Diagnostics, Pasadena, CA), CF v3.0 oligonucleotide ligation assay (Abbott Laboratories, Abbott Park, IL/Celera Diagnostics, Alameda, CA), Signature CF 2.0 ASR (Asuragen, Austin, TX), and Tag-It Mutation Detection Kit for CFTR (TM Biosciences, Toronto, Canada) technologies on the same sample of CFTR templates. ${ }^{77}$ The Invader assay exhibited the least cost for instrumentation ( $\$ 12,900$ vs. $\$ 45,000$ to $\$ 145,000)$, the least cost of reagents per patient sample ( $\$ 39.00$ vs. $\$ 45.00$ to $\$ 64.00)$, the least hands-on operator time ( $<1$ hour vs. 1 to 2.5 hours), and the least start to finish time ( 4 hours vs. 5 to 8 hours). While the Inplex microfluidics card and the PCR-independent and PCR-dependent microtiter platforms of the present investigation lack a number of features in common, they are generally equivalent in consumption of reagents other than oligonucleotide probes, instrumentation, operator time and start to finish time. Similar comparisons of methods testing identical polymorphisms on identical templates are needed to determine whether these advantages are shared with invader formats and platforms designed for perioperative use.

Prior to routine applications in the interval surrounding surgery, any chosen genotyping method must first be shown to exert a beneficial effect on patient outcomes in blinded, prospective trials. To this end, the inclusion of additional alleles underlying traits of perioperative significance will add to economies of scale, e.g., polymorphisms that correlate with analgesic requirements (e.g., polymorphisms in OPRM1, the gene encoding the $u$-opioid receptor), cardiac dysrhythmia and ischemia, and malignant hyperthermia. Methods that are sensitive to other mechanisms of inherited predisposition may also be desired including, for example, alternate splicing, epigenomic variation, variable number tandem repeats, copy number polymorphisms and haplotype analysis. In all likelihood, the number of assays necessary to directly detect these and other DNA variations will require higher order miniaturization and automation than that reported here. Nevertheless, the probe-sets and formats of the present investigation are easily adaptable to both intermediate- (e.g., 384-well microtiter plates) and high-throughput (e.g., solid phase microarray) platforms.
An established genotype-phenotype correlation for each allele was a primary criterion for its incorporation into the perioperative genomic profile, thus the present investigation was not designed to address the clinical validity of the individual genotypes selected for inclusion. Nor do the present results establish the clinical utility of individual alleles, or of the profile as a whole in a perioperative context. Such an investigation awaits the availability and validity of a suitable genotyping platform. While the observed allele frequencies for the preponderance of polymorphisms comprising the perioperative genomic profile were in close accord with earlier reports (table 5), it is not possible on the basis of the present results to determine if the divergent allele frequencies we observed at $\mathrm{ABO}$ blood group and hepatic drug metabolism loci arise from population stratification, founder effects, or non-random sampling. Larger sample sizes with specific experimental designs (e.g., incorporation of haplotype data at multiple loci and documentation of ancestral ethnic origins) are required to confirm or refute the observed differences, and to resolve the underlying mechanisms. Nevertheless, these differences underscore the potential benefit of tailoring selection of the components of a perioperative genomic profile to its intended target population. Accordingly, a primary objective of the present investigation was to guide the design of an efficient platform based on knowledge of allele frequencies in a specific target population.

Over 200 million surgical procedures are performed worldwide each year. ${ }^{78}$ Current data indicate that the overall mortality rate during and immediately after surgery from any cause, for any procedure and for all categories of physical status approaches 1 per 500 anesthetics. ${ }^{79}$ Multiple studies document a consistent profile of perioperative risk, in which the overall incidence of complications is at least $20 \%$ with moderate, severe or catastrophic sequelae observed in over $3 \%$ of patients. ${ }^{80-82} \mathrm{~A}$ high proportion of these adverse outcomes are strongly associated with genetic predispositions including thrombosis, bronchospasm, cardiac dysrhythmia and sepsis. Others reflect pharmacokinetic and pharmacodynamic genomic susceptibilities that are unknown in advance of exposure to drugs first encountered in perioperative care. ${ }^{83}$ Affected patients survive because deleterious events are recognized while rescue measures are still effective. ${ }^{84}$ In practice, perioperative drug regimens are determined through test doses, trial infusions and one-size-fits-all protocols (i.e., all patients of a given weight), and are reinforced as needed with the immediate availability of countermeasures and antidotes. Nevertheless, the high incidence of morbidity and mortality that accompanies surgical procedures indicates that current practices too often fall short.

At present, genetic screening is not performed prior to surgery despite rapidly expanding identification of relevant alleles. The gap between use of abundant and high quality DNA-based predictors and contemporary screening practice, which consists of a family medical history checkbox on a preoperative evaluation form, is best explained by the lack of a genotypic technology that has been specifically configured 
for perioperative use. While the majority of genetic variations identified thus far to be of value in perioperative care express monogenic traits, their ultimate effects on patient outcome may in fact involve the participation of multiple gene products. Thus, a single patient may have multiple mutant alleles within one or more loci or pathways that contribute to disease predisposition and response to its management (e.g., susceptibility to thrombosis via $F 2$ and $F 5$ polymorphisms, and response to anticoagulation via $C Y P 2 C 9$ polymorphisms), thereby highlighting the advantages of genomic profiling for an array of alleles in the perioperative setting.

A key step in bringing "personalized medicine" to the operating room is availability of a genotyping method that combines high precision, operator safety, timely and unambiguous results, and that can be adapted to conform to the regulatory requirements and financial constraints of clinical laboratories faced with testing multiple alleles on each of many tens to hundreds of patients on a daily surgical schedule. The present results show that molecular surveillance in the perioperative interval using structure-specific cleavage of oligonucleotide probes is analytically valid and well-suited to the detection of alleles with diverse DNA sequence variations, allele frequencies, and mechanisms of inheritance, penetrance and expressivity of associated traits. In the alternative, failing to genotype in the perioperative interval risks penalizing genetic outliers, a category that the genomic profiles of the present investigation suggest may well include us all in turn.

\section{REFERENCES}

1. Podgoreanu MV, Mathew JP. Genomic basis of perioperative medicine. In: Barash PG, Cullen BF, Stoelting RK, eds. Clinical anesthesia. $5^{\text {th }}$ ed. Philadelphia, PA: Lippincott Williams \& Wilkins; 2006. 133-148.

2. Yu SF, Wu LH, Zheng SS. Genetic factors for individual administration of immunosuppressants in organ transplantation. Hepatobiliary Pancreat Dis Int 2006;5: 337-344.

3. Sakaeda T, Nakamura T, Okumura K. Pharmacogenetics of MDR1 and its impact on the pharmacokinetics and pharmacodynamics of drugs. Pharmacogenomics 2003;4: 397-410.

4. Babaoglu MO, Bayar B, Aynacioglu AS, Kerb R, Abali H, Celik I, Bozkurt A. Association of the ABCB1 $3435 \mathrm{C}>\mathrm{T}$ polymorphism with antiemetic efficacy of 5-hydroxytryptamine type 3 antagonists. Clin Pharmacol Ther 2005;78:619-626.

5. Gätke MR, Ostergaard D, Bundgaard JR, Varin F, Viby-Mogensen J. Response to mivacurium in a patient compound heterozygous for a novel and a known silent mutation in the butyrylcholinesterase gene. Anesthesiology 2001;95:600-606.

6. Kalow W, Grant DM. Pharmacogenetics. In: Scriver CR, Beaudet AL, Sly WS, Valle D, eds. The metabolic and molecular bases of inherited disease. $8^{\text {th }}$ ed. New York, NY: McGaw-Hill; 2001. 225-255.

7. Barta C, Sasvari-Szekely M, Devai A, Kovacs E, Staub M, Enyedi P. Analysis of mutations in the plasma cholinesterase gene of patients with a history of prolonged neuromuscular block during anesthesia. Mol Genet Metab 2001;74:484-488.
8. McNamara DM, Holubkov R, Postava L, Janosko K, MacGowan GA, Mathier M, Murali S, Feldman AM, London B.

Pharmacogenetic interactions between angiotensin-converting enzyme inhibitor therapy and the angiotensin-converting enzyme deletion polymorphism in patients with congestive heart failure. J Am Coll Cardiol 2004;44:2019-2026.

9. Lasocki S, Iglarz M, Seince PF, Vuillaumier-Barrot S, Vicaut E, Henrion D, Levy B, Desmonts JM, Philip I, Bénessiano J. Involvement of renin-angiotensin system in pressure-flow relationship: role of angiotensin-converting enzyme gene polymorphism. Anesthesiology 2002;96:271-275.

10. Völzke H, Engel J, Kleine V, Schwahn C, Dahm JB, Eckel L, Rettig R. Angiotensin I-converting enzyme insertion/deletion polymorphism and cardiac mortality and morbidity after coronary artery bypass graft surgery. Chest 2002;122:31-36.

11. Yende S, Quasney MW, Tolley EA, Wunderink RG. Clinical relevance of angiotensin-converting enzyme gene polymorphisms to predict risk of mechanical ventilation after coronary artery bypass graft surgery. Crit Care Med 2004;32:922-927.

12. Hillman MA, Wilke RA, Yale SH, Vidaillet HJ, Caldwell MD, Glurich I, Berg RL, Schmelzer J, Burmester JK. A prospective, randomized pilot trial of model-based warfarin dose initiation using CYP2C9 genotype and clinical data. Clin Med Res 2005;3:137-145.

13. Kirchheiner J, Brockmöller J. Clinical consequences of cytochrome P450 2C9 polymorphisms. Clin Pharmacol Ther 2005;77:1-16.

14. Aquilante CL, Langaee TY, Lopez LM, Yarandi HN, Tromberg JS, Mohuczy D, Gaston KL, Waddell CD, Chirico MJ, Johnson JA. Influence of coagulation factor, vitamin K epoxide reductase complex subunit 1 , and cytochrome P450 2C9 gene polymorphisms on warfarin dose requirements. Clin Pharmacol Ther 2006;79:291-302.

15. Wadelius M, Chen LY, Eriksson N, Bumpstead S, Ghori J, Wadelius C, Bentley D, McGinnis R, Deloukas P. Association of warfarin dose with genes involved in its action and metabolism. Hum Genet 2007;121:23-34.

16. Schwarz UI, Ritchie MD, Bradford Y, Li C, Dudek SM, Frye-Anderson A, Kim RB, Roden DM, Stein CM. Genetic determinants of response to warfarin during initial anticoagulation. N Engl J Med 2008;358:999-1008.

17. Klotz U. Clinical impact of CYP2C19 polymorphism on the action of proton pump inhibitors: a review of a special problem. Int J Clin Pharmacol Ther 2006;44:297-302.

18. Inomata S, Nagashima A, Itagaki F, Homma M, Nishimura M, Osaka Y, Okuyama K, Tanaka E, Nakamura T, Kohda Y, Naito S, Miyabe M, Toyooka H. CYP2C19 genotype affects diazepam pharmacokinetics and emergence from general anesthesia. Clin Pharmacol Ther 2005;78:647-655.

19. Caraco Y, Sheller J, Wood AJ. Pharmacogenetic determination of the effects of codeine and prediction of drug interactions. J Pharmacol Exp Ther 1996:278:1165-1174.

20. Janicki PK, Schuler HG, Jarzembowski TM, Rossi M 2nd. Prevention of postoperative nausea and vomiting with granisetron and dolasetron in relation to CYP2D6 genotype. Anesth Analg 2006;102:1127-1133.

21. Gasche Y, Daali Y, Fathi M, Chiappe A, Cottini S, Dayer P, Desmeules J. Codeine intoxication associated with ultrarapid CYP2D6 metabolism (erratum appears in: N Engl J Med 2005;352:638.). N Engl J Med 2004;351:2827-2831.

22. Stamer UM, Musshoff F, Kobilay M, Madea B, Hoeft A, Stuber F. Concentrations of tramadol and O-desmethyltramadol enantiomers in different CYP2D6 genotypes. Clin Pharmacol Ther 2007;82:41-47. 
23. Candiotti KA, Birnbach DJ, Lubarsky DA, Nhuch F, Kamat A, Koch WH, Nikoloff M, Wu L, Andrews D. The impact of pharmacogenomics on postoperative nausea and vomiting: do CYP2D6 allele copy number and polymorphisms affect the success or failure of ondansetron prophylaxis? Anesthesiology 2005; 102:543-549.

24. Lin YS, Dowling AL, Quigley SD, Farin FM, Zhang J, Lamba J, Schuetz EG, Thummel KE. Co-regulation of CYP3A4 and CYP3A5 and contribution to hepatic and intestinal midazolam metabolism. Mol Pharmacol 2002;62:162-172.

25. Tsuchiya N, Satoh S, Tada H, Li Z, Ohyama C, Sato K, Suzuki T, Habuchi T, Kato T. Influence of CYP3A5 and MDRI ( $A \mathrm{BCB} 1)$ polymorphisms on the pharmacokinetics of tacrolimus in renal transplant recipients. Transplantation 2004;78:1182-1187.

26. Dai Y, Hebert MF, Isoherranen N, Davis CL, Marsh C, Shen DD, Thummel KE. Effect of CYP3A5 polymorphism on tacrolimus metabolic clearance in vitro. Drug Metab Dispos 2006;34:836-847.

27. Park JY, Kim KA, Park PW, Lee OJ, Kang DK, Shon JH, Liu KH, Shin JG. Effect of CYP $3 A 5^{*} 3$ genotype on the pharmacokinetics and pharmacodynamics of alprazolam in healthy subjects. Clin Pharmacol Ther 2006;79:590-599.

28. Kim NS, Lee IO, Lee MK, Lim SH, Choi YS, Kong MH. The effects of beta 2 adrenoceptor gene polymorphisms on pressor response during laryngoscopy and tracheal intubation. Anaesthesia 2002;57:227-232.

29. Kaymak C, Kocaba? NA, Durmaz E, Oztuna D. beta2 adrenoceptor (ADRB2) pharmacogenetics and cardiovascular phenotypes during laryngoscopy and tracheal intubation. Int J Toxicol 2006;25:443-449.

30. Hawkins GA, Tantisira K, Meyers DA, Ampleford EJ, Moore WC, Klanderman B, Liggett SB, Peters SP, Weiss ST, Bleecker ER. Sequence, haplotype, and association analysis of ADRbeta2 in a multiethnic asthma case-control study. Am J Respir Crit Care Med 2006;174:1101-1109.

31. Schaeffeler E, Fischer C, Brockmeier D, Wernet D, Moerike K, Eichelbaum M, Zanger UM, Schwab M. Comprehensive analysis of thiopurine S-methyltransferase phenotype-genotype correlation in a large population of German-Caucasians and identification of novel TPMT variants. Pharmacogenetics 2004;14:407-417.

32. Doggen CJ, Cats VM, Bertina RM, Rosendaal FR. Interaction of coagulation defects and cardiovascular risk factors: increased risk of myocardial infarction associated with factor $\mathrm{V}$ Leiden or prothrombin 20210A. Circulation 1998;97:1037-1041.

33. Welsby IJ, Podgoreanu MV, Phillips-Bute B, Mathew JP, Smith PK, Newman MF, Schwinn DA, Stafford-Smith M; Perioperative Genetics and Safety Outcomes Study (PEGASUS) Investigative Team. Genetic factors contribute to bleeding after cardiac surgery. J Thromb Haemost 2005;3:1206-1212.

34. Donahue BS, Gailani D, Higgins MS, Drinkwater DC, George AL Jr. Factor V Leiden protects against blood loss and transfusion after cardiac surgery. Circulation 2003;107: 1003-1008.

35. Donahue BS. Factor V Leiden and perioperative risk. Anesth Analg 2004;98:1623-1634.

36. Edmonds MJ, Crichton TJ, Runciman WB, Pradhan M. Evidence-based risk factors for postoperative deep vein thrombosis. ANZ J Surg 2004;74:1082-1097.

37. Campo G, Valgimigli M, Ferraresi P, Malagutti P, Baroni M, Arcozzi C, Gemmati D, Percoco G, Parrinello G, Ferrari $\mathrm{R}$, Bernardi F. Tissue factor and coagulation factor VII levels during acute myocardial infarction: association with genotype and adverse events. Arterioscler Thromb Vasc Biol 2006;26:2800-2806
38. Botto N, Andreassi MG, Rizza A, Berti S, Bevilacqua S, Federici C, Palmieri C, Glauber M, Biagini A. C677T polymorphism of the methylenetetrahydrofolate reductase gene is a risk factor of adverse events after coronary revascularization. Int J Cardiol 2004;96:341-345.

39. Selzer RR, Rosenblatt DS, Laxova R, Hogan K. Adverse effect of nitrous oxide in a child with 5,10-methylenetetrahydrofolate reductase deficiency. N Engl J Med 2003;349:45-50.

40. Stuber F, Petersen M, Bokelmann F, Schade U. A genomic polymorphism within the tumor necrosis factor locus influences plasma tumor necrosis factor-alpha concentrations and outcome of patients with severe sepsis. Crit Care Med 1996;24:381-384.

41. Shaw AD, Vaporciyan AA, Wu X, King TM, Spitz MR, Putnam JB, Dickey BF. Inflammatory gene polymorphisms influence risk of postoperative morbidity after lung resection. Ann Thorac Surg 2005;79:1704-1710.

42. Holweg CT, Weimar W, Uitterlinden AG, Baan CC. Clinical impact of cytokine gene polymorphisms in heart and lung transplantation. J Heart Lung Transplant 2004;23:1017-1026.

43. Bittar MN, Carey JA, Barnard JB, Pravica V, Deiraniya AK, Yonan N, Hutchinson IV. Tumor necrosis factor alpha influences the inflammatory response after coronary surgery. Ann Thorac Surg 2006;81:132-137.

44. Khalil AA, Hall JC, Aziz FA, Price P. Tumour necrosis factor: implications for surgical patients. ANZ J Surg 2006;76:10101016.

45. Tomasdottir H, Hjartarson H, Ricksten A, Wasslavik C, Bengtsson A, Ricksten SE. Tumor necrosis factor gene polymorphism is associated with enhanced systemic inflammatory response and increased cardiopulmonary morbidity after cardiac surgery. Anesth Analg 2003; 97:944949.

46. Ryan R, Thornton J, Duggan E, McGovern E, O’Dwyer MJ, Ryan AW, Kelleher D, McManus R, Ryan T. Gene polymorphism and requirement for vasopressor infusion after cardiac surgery. Ann Thorac Surg 2006;82:895-901.

47. Abdi R, Tran TB, Sahagun-Ruiz A, Murphy PM, Brenner BM, Milford EL, McDermott DH. Chemokine receptor polymorphism and risk of acute rejection in human renal transplantation. J Am Soc Nephrol 2002;13:754-758.

48. Nischalke HD, Nattermann J, Lichterfeld M, Woitas RP, Rockstroh JK, Sauerbruch T, Spengler U. Rapid determination of the Delta32 deletion in the human CC-chemokine receptor 5 (CCR5) gene without DNA extraction by lightcycler real-time polymerase chain reaction. AIDS Res Hum Retroviruses 2004;20:750-754.

49. Lelis RG, Krieger JE, Pereira AC, Schmidt AP, Carmona MJ, Oliveira SA, Auler JO Jr. Apolipoprotein E4 genotype increases the risk of postoperative cognitive dysfunction in patients undergoing coronary artery bypass graft surgery. J Cardiovasc Surg (Torino) 2006;47:451-456.

50. MacKensen GB, Swaminathan M, Ti LK, Grocott HP, Phillips-Bute BG, Mathew JP, Newman MF, Milano CA, Stafford-Smith M; Perioperative Outcomes Research Group; Cardiothoracic Anesthesiology Research Endeavors (C.A.R.E.) Investigators of the Duke Heart Center. Preliminary report on the interaction of apolipoprotein E polymorphism with aortic atherosclerosis and acute nephropathy after CABG. Ann Thorac Surg 2004;78:520-526.

51. Stafford-Smith M, Podgoreanu M, Swaminathan M, Phillips-Bute B, Mathew JP, Hauser EH, Winn MP, Milano C, Nielsen DM, Smith M, Morris R, Newman MF, Schwinn DA; Perioperative Genetics and Safety Outcomes Study (PEGASUS) Investigative Team. Association of genetic polymorphisms with risk of renal injury after coronary bypass graft surgery. Am J Kidney Dis 2005;45:519-530. 
52. Grocott HP, Newman MF, El-Moalem H, Bainbridge D, Butler A, Laskowitz DT. Apolipoprotein E genotype differentially influences the proinflammatory and anti-inflammatory response to cardiopulmonary bypass. J Thorac Cardiovasc Surg 2001;122:622-623.

53. Heyer EJ, Wilson DA, Sahlein DH, Mocco J, Williams SC, Sciacca R, Rampersad A, Komotar RJ, Zurica J, Benvenisty A, Quest DO, Todd G, Solomon RA, Connolly ES Jr. APOE-epsilon4 predisposes to cognitive dysfunction following uncomplicated carotid endarterectomy. Neurology 2005;65:1759-1763.

54. Mason P. Sickle cell disease in the perioperative setting. J Perioper Pract 2006;16:443-446.

55. Poliac LC, Barron ME, Maron BJ. Hypertrophic cardiomyopathy. Anesthesiology 2006;104:183-192.

56. Westhoff CM. Molecular testing for transfusion medicine. Curr Opin Hematol 2006;13:471-475.

57. Izrailtyan I, Podgoreanu M, Phillips-Bute B, Stafford-Smith M, Milano C, Schwinn D, Newman M, Matthew J. Gender related differences in genetic polymorphisms and major adverse outcomes following cardiac surgery. Anesth Analg 2005;100:SCA25.

58. Schiebel K, Mertz A, Winkelmann M, Gläser B, Schempp W, Rappold G. FISH localization of the human Y-homolog of protein kinase PRKX (PRKY) to Yp11.2 and two pseudogenes to $15 \mathrm{q} 26$ and Xq12-q13. Cytogenet. Cell Genet 1997;76:49-52.

59. Batra RS, Hatchwell E, Rider S, Brown R, Brown GK, Craig IW. Localization of human liver 6-phosphofructo-2-kinase/ fructose-2,6-bisphosphatase (PFKFB1) within a YAC contig in Xp11.21. Genomics 1997;40:358-361.

60. Olivier M. The Invader assay for SNP genotyping. Mutat Res 2005;573:103-110.

61. Kim RB, Leake BF, Choo EF, Dresser GK, Kubba SV, Schwarz UI, Taylor A, Xie HG, McKinsey J, Zhou S, Lan LB, Schuetz JD, Schuetz EG, Wilkinson GR. Identification of functionally variant MDR1 alleles among European Americans and African Americans. Clin Pharmacol Ther 2001;70:189-199.

62. Boeck AT, Fry DL, Sastre A, Lockridge O. Naturally occurring mutation, Asp70his, in human butyrylcholinesterase. Ann Clin Biochem 2002;39(Pt 2):154-156.

63. Zee RY, Cook NR, Cheng S, Reynolds R, Erlich HA, Lindpaintner K, Ridker PM. Polymorphism in the P-selectin and interleukin- 4 genes as determinants of stroke: a population-based, prospective genetic analysis. Hum Mol Genet 2004;13:389-396.

64. Moridani M, Fu L, Selby R, Yun F, Sukovic T, Wong B, Cole DE. Frequency of $C Y P 2 C 9$ polymorphisms affecting warfarin metabolism in a large anticoagulant clinic cohort. Clin Biochem 2006;39:606-612.

65. Blaisdell J, Mohrenweiser H, Jackson J, Ferguson S, Coulter S, Chanas B, Xi T, Ghanayem B, Goldstein JA. Identification and functional characterization of new potentially defective alleles of human CYP2C19. Pharmacogenetics 2002;12: 703-711.

66. Chou WH, Yan FX, Robbins-Weilert DK, Ryder TB, Liu WW, Perbost C, Fairchild M, de Leon J, Koch WH, Wedlund PJ. Comparison of two CYP2D6 genotyping methods and assessment of genotype-phenotype relationships. Clin Chem 2003;49:542-551.

67. Marez D, Legrand M, Sabbagh N, Guidice JM, Spire C, Lafitte JJ, Meyer UA, Broly F. Polymorphism of the cytochrome P450 CYP2D6 gene in a European population: characterization of 48 mutations and 53 alleles, their frequencies and evolution. Pharmacogenetics 1997;7: 193-202.
68. Lamba JK, Lin YS, Thummel K, Daly A, Watkins PB, Strom S, Zhang J, Schuetz EG. Common allelic variants of cytochrome P4503A4 and their prevalence in different populations. Pharmacogenetics 2002;12:121-132.

69. Floyd MD, Gervasini G, Masica AL, Mayo G, George AL Jr, Bhat K, Kim RB, Wilkinson GR. Genotype-phenotype associations for common $C Y P 3 A 4$ and $C Y P 3 A 5$ variants in the basal and induced metabolism of midazolam in Europeanand African-American men and women. Pharmacogenetics 2003;13:595-606.

70. Otterness D, Szumlanski C, Lennard L, Klemetsdal B, Aarbakke J, Park-Hah JO, Iven H, Schmiegelow K, Branum E, O’Brien J, Weinshilboum R. Human thiopurine methyltransferase pharmacogenetics: gene sequence polymorphisms. Clin Pharmacol Ther 1997;62:60-73.

71. Yan L, Zhang S, Eiff B, Szumlanski CL, Powers M, O'Brien JF, Weinshilboum RM. Thiopurine methyltransferase polymorphic tandem repeat: genotype-phenotype correlation analysis. Clin Pharmacol Ther 2000;68:210-219.

72. Rady PL, Szucs S, Grady J, Hudnall SD, Kellner LH, Nitowsky H, Tyring SK, Matalon RK. Genetic polymorphisms of methylenetetrahydrofolate reductase (MTHFR) and methionine synthase reductase (MTRR) in ethnic populations in Texas; a report of a novel MTHFR polymorphic site, G1793A. Am J Med Genet 2002;107:162-168.

73. Lorey FW, Arnopp J, Cunningham GC. Distribution of hemoglobinopathy variants by ethnicity in a multiethnic state. Genet Epidemiol 1996;13:501-512.

74. Ackerman MJ, VanDriest SL, Ommen SR, Will ML, Nishimura RA, Tajik AJ, Gersh BJ. Prevalence and age-dependence of malignant mutations in the beta-myosin heavy chain and troponin $\mathrm{T}$ genes in hypertrophic cardiomyopathy: a comprehensive outpatient perspective. J Am Coll Cardiol 2002;39:2042-2048.

75. Yip SP. Single-tube multiplex PCR-SSCP analysis distinguishes 7 common $\mathrm{ABO}$ alleles and readily identifies new alleles. Blood 2000;95:1487-1492.

76. Pompanon F, Bonin A, Bellemain E, Taberlet P. Genotyping errors: causes, consequences and solutions. Nat Rev Genet 2005;6:847-859.

77. Johnson MA, Yoshitomi MJ, Richards CS. A comparative study of five technologically diverse CFTR testing platforms. J Mol Diagn 2007;9:401-407.

78. Weiser TG, Regenbogen SE, Thompson KD, Haynes AB, Lipsitz SR, Berry WR, Gawande AA. An estimation of the global volume of surgery: a modelling strategy based on available data. Lancet 2008;372:139-144.

79. Lagasse RS. Anesthesiology safety: model or myth? A review of the published literature and analysis of current original data. Anesthesiology 2002;97:1609-1617.

80. Bothner U, Georgieff M, Schwilk B. Building a large-scale perioperative anaesthesia outcome-tracking database: methodology, implementation, and experiences from one provider within the German quality project. Br J Anaesth 2000;85:271-280.

81. Cohen MM, Duncan PG, Pope WD, Biehl D, Tweed WA, MacWilliam L, Merchant RN. The Canadian four-centre study of anaesthetic outcomes: II. Can outcomes be used to assess the quality of anaesthesia care? Can J Anaesth 1992;39:430-439.

82. Forrest JB, Rehder K, Cahalan MK, Goldsmith CH. Multicenter study of general anesthesia. III. Predictors of severe perioperative adverse outcomes. Anesthesiology 1992;7 6:3-15.

83. Hogan K. Pharmacogenetics and pharmacogenomics of drug action. In: Anesthetic pharmacology; Physiologic principles and clinical practice. Evers AS, Maze M, eds. 2nd ed. St. Louis, MO: Harcourt, Inc.; 2004. 79-90. 
84. Sigurdsson GH, McAteer E. Morbidity and mortality associated with anaesthesia. Acta Anaesthesiol Scand 1996;40: 1057-1063.

\section{AUTHOR AFFILIATIONS}

Kirk J. Hogan, MD

Department of Anesthesiology

University of Wisconsin School of Medicine and Public Health

Madison, Wisconsin 53792

James K. Burmester, PhD

Center for Human Genetics

Marshfield Clinic Research Foundation

Marshfield, Wisconsin 54449

Michael D. Caldwell, MD, PhD

Department of Surgery

Marshfield Clinic

Marshfield, Wisconsin 54449

Quinn H. Hogan, MD

Department of Anesthesiology

Medical College of Wisconsin, and

Zablocki Veteran's Administration Medical Center

Milwaukee, Wisconsin 53226

Douglas B. Coursin, MD

Departments of Anesthesiology and Medicine

University of Wisconsin School of Medicine and Public Health

Madison, Wisconsin 53792

Dawn N. Green, MS

Department of Anesthesiology

University of Wisconsin School of Medicine and Public Health

Madison, Wisconsin 53792

Present address:

Roche NimbleGen, Inc.

Madison, Wisconsin 53701

Rebecca M.R. Selzer PhD

Department of Anesthesiology

University of Wisconsin School of Medicine and Public Health

Madison, Wisconsin 53792

Present address:

Roche NimbleGen, Inc.

Madison, Wisconsin 53701

Thomas P. Broderick, MD

Department of Anesthesiology

University of Wisconsin School of Medicine and Public Health

Madison, Wisconsin 53792
Deborah A. Rusy, MD

Department of Anesthesiology

University of Wisconsin School of Medicine and Public Health

Madison, Wisconsin 53792

Mark Poroli, BS

Department of Anesthesiology

Medical College of Wisconsin, and

Zablocki Veteran's Administration Medical Center

Milwaukee, Wisconsin 53226

Anna L. Lutz, BS

Third Wave Technologies, Inc.

Madison, Wisconsin 53719

Allison M. Sanders, BS

Third Wave Technologies, Inc.

Madison, Wisconsin 53719

Mary C. Oldenburg, $M S$

Third Wave Technologies, Inc.

Madison, Wisconsin 53719

James A. Koelbl, MS

Third Wave Technologies, Inc.

Madison, Wisconsin 53719

Monika de Arruda-Indig, PhD

Third Wave Technologies, Inc.

Madison, Wisconsin 53719

Present address:

Blood Center of Wisconsin

Milwaukee, Wisconsin 53201

Jennifer L. Halsey, PharmD

Department of Anesthesiology

University of Wisconsin School of Medicine and Public Health

Madison, Wisconsin 53792

Present address:

Aurora West Allis Medical Center

West Allis, Wisconsin 53227

Stephen P. Day, PhD

Third Wave Technologies, Inc.

Madison, Wisconsin 53719

Michael J. Domanico, PhD

Third Wave Technologies, Inc.

Madison, Wisconsin 53719 